Article

\title{
Structure and composition of basement and sedimentary cover in the southwestern part of the Siljan Ring, central Sweden: new data from the C-C-1 drill core
}

\author{
Olga Sivalneva ${ }^{1}$, Alexandr Postnikov ${ }^{1}$, Vladimir Kutcherov ${ }^{1,2}, *$, Marianna Tuchkova ${ }^{3}$, Alexandr Buzilov ${ }^{4}$, Viktor $^{2}$ \\ Martynov ${ }^{1}$, Ilnur Sabirov ${ }^{1}$, Elisaveta Idrisova ${ }^{5}$
}

1 Gubkin Russian State University of Oil and Gas (National Research University), Moscow, 119991, Russia; sivalneva.o@gubkin.ru (O.S.); apostnikov@gubkin.ru (A.P.); com@gubkin.ru (V.M.); sabirov.i@gubkin.ru (I.S.)

2 KTH Royal Institute of Technology, Stockholm, SE-100 44, Sweden; vladimir.kutcherov@indek.kth.se (V.K.)

3 Geological Institute, Russian Academy of Sciences (GIN RAS), Moscow, 119017, Russia; tuchkova@ginras.ru (M.T.)

4 PANGEA Inc., Moscow,127015, Russia; huntershole@yandex.ru (A.B.)

5 Skolkovo Institute of Science and Technology, Moscow,121205, Russia; Elizaveta.Idrisova@skoltech.ru (E.I.)

* Correspondence: vladimir.kutcherov@indek.kth.se

\begin{abstract}
Results of geological and geophysical investigations of the Siljan Ring impact structure (central Sweden) revealed complicated relationships between Paleozoic sedimentary succession and the Precambrian basement. Tectonic and depositional evolution caused complex geology. Studies of a new drill core from the C-C-1 well provide information necessary for the reconstruction of the geological setting in the southwestern part of Siljan Ring. The whole interval of the core section is from 32.60 to $634.90 \mathrm{~m}$ with almost no breaks. The sedimentary cover is $373.55 \mathrm{~m}$ thick in total. The sedimentary sequences are predominantly composed of wackestones, mudstones, and shales. In the lower part of the sedimentary section, limestone layers intercalate with black shales. In a result of the investigations, it has been suggested that sedimentary layers represent Late Ordovician and Silurian deposits and have disturbed stratigraphic relations. The basement section is composed of Precambrian meta-volcanic and meta-sedimentary rocks. The contact between the basement and the sedimentary cover is tectonic, not normal sedimentary, in origin. Tectonic processes caused intensive rock fracturing. Four generations of fractures were identified with analysis of fracture relations and mineralization sequence. Only two of them occur in sedimentary rocks that probably belong to the latest stages of tectonic activity. Highly fractured basement rocks in some cases contain open vugs developed along the fractures. Rock matrix is tight either in sedimentary and basement rocks and only micro-porosity space is recognized in cataclastic zones. Single evidence of bituminous filling of micro-porosity zone and partly cemented vug is established in limestone from the lower part of the sedimentary section. These findings are particularly valuable for stratigraphy refinement and tectonic setting reconstructions as well as oil and gas reservoir forecasts.
\end{abstract}

Keywords: Siljan Ring; Precambrian; Ordovician-Silurian; meta-sedimentary rocks; fractures; reservoir

\section{Introduction}

The Siljan Ring is considered one of the largest impact structures and has a long history of investigations, for both scientific and applied purposes. The detailed historical overview of this research is given in a report of the 9th WOGOGOB meeting [7]. Results of geophysical studies, especially more detailed recent analysis $[9,10,11,15,16]$, provide valuable information about the geological complexity of the area that includes structural and stratigraphy interrelations. That complexity results from the high paleo-tectonic activity of the area and superimposed deformation due to orogenic events.

Since the first report of crude oil by Carl von Linné in 1734, the Siljan Ring area has attracted interest as a prospective site for oil and gas exploration [1]. 
Petroleum reserves in meteor impact craters possess great potential. Oil and natural gas deposits have been found in onshore and offshore meteor impact crater carbonate, sandstone, and granite rocks over the world. Between 1986-1990 two deep wells were drilled in the Siljan Ring area in order to evaluate this crater for commercial abiogenic gas production as part of the Swedish Deep Gas Drilling project. Although the results of this project were disappointing as regards commercial exploration opportunities, it did not prevent well drilling by the Swedish company Igrene AB. Published results of two core section investigations (Mora 1 and Solberga 1) [17] provided important sedimentological and stratigraphic information about the sedimentary cover structure in the western and eastern parts of the Siljan Ring. Recently, comprehensive studies of the Stumsnäs 1 core $[2,18]$ highlighted some questions about fracture distribution and mineralization in basement rocks.

This study summarizes results of detailed petrologic investigations of drill core from a new C-C-1 well drilled in the southwestern part of the Siljan Ring. These results allowed the creation of lithology and petrography columns with descriptions of alteration processes such as fracturing and subsequent mineralization. Combined with pore space characteristics such descriptions highlight possible reservoir intervals throughout the well section.

New information is very valuable for stratigraphy refinement and tectonic setting reconstructions. The results obtained are useful for suggesting the maximum tectonic activity phases and position of faults. Moreover, it is a basis for establishing the origin and distribution of reservoir rocks.

\section{Geological settings}

The Siljan Ring structure is known as a late Devonian (380.9 $\pm 4.6 \mathrm{Ma})$ [14] impact crater located in central Sweden. The structure is of circular shape with a central rise of approximately $33 \mathrm{~km}$ in diameter (Fig. 1). The central area consists of Proterozoic magmatic, meta-volcanic and meta-sedimentary rocks. The structure belongs to the TransScandinavian Igneous Belt, and magmatic rocks are predominantly Dala granites (Järna and Siljan type) with sporadically occurring mafic intrusions [13].

Sedimentary cover is preserved only inside the depression surrounding the central uplift. It comprises a Paleozoic succession of Ordovician to Silurian sediments. The thickness of the sedimentary sequence was estimated at up to $500 \mathrm{~m}$ [16]. In the inner part and outer periphery of the Siljan area, sedimentary strata have opposite dips due to strongly tilting and tectonic deformation [12].

The Ordovician sedimentary rocks unconformably overlie the Proterozoic basement and consist predominantly of limestones with some shales - Tøyen Formation and Fjäcka Shale (Fig. 2) [5,7,18].

The lower Silurian section (Llandovery-Wenlock) comprises of marls, nodular limestones, shales, mudstones and sandstones [5,17].

The established stratigraphy was greatly refined by studies on the new Mora 1 and Solberga 1 drill cores (Fig. 3) [17]. If compared with the typical Ordovician and Silurian succession of the Siljan region, a considerable part of the section was missing in the Mora area: mostly the Middle and Upper Ordovician carbonates, which are preserved in the eastern part of the impact structure. The upper part of the section contains a Silurian siliciclastic succession which unconformably overlies Middle Ordovician limestones. A classical Ordovician-Silurian carbonate-shale succession has been described from the Solberga 1 drill core, though stratigraphic disturbance by two thrust planes complicates the geological interpretation. These core studies result in suggestions about the differentiation of Ordovician-Silurian facies belts that developed during the passage of the carbonate platform environments to continental conditions [17]. 


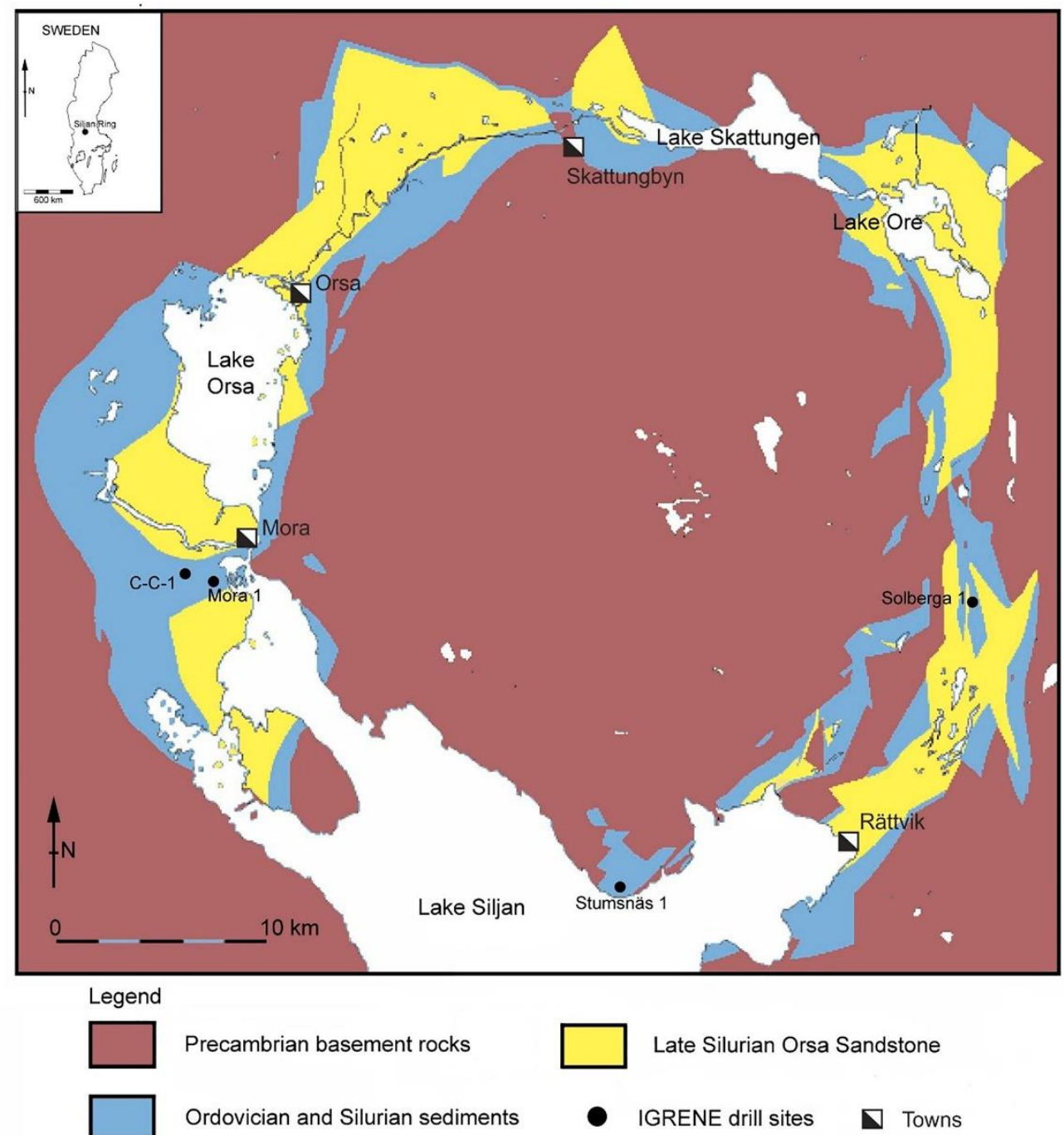

Figure 1. Simplified geological map of the Siljan Ring structure, showing the locations of IGRENE drill sites.

The ring structure is identified as a ring graben [16] divided into mega-blocks by faults with significant horizontal displacements. It is clearly visible on seismic reflection that basement blocks and sedimentary successions are often sharply inclined or overturned. Such geological complications are interpreted to be results of the Caledonian orogeny and posterior Devonian impact event. 


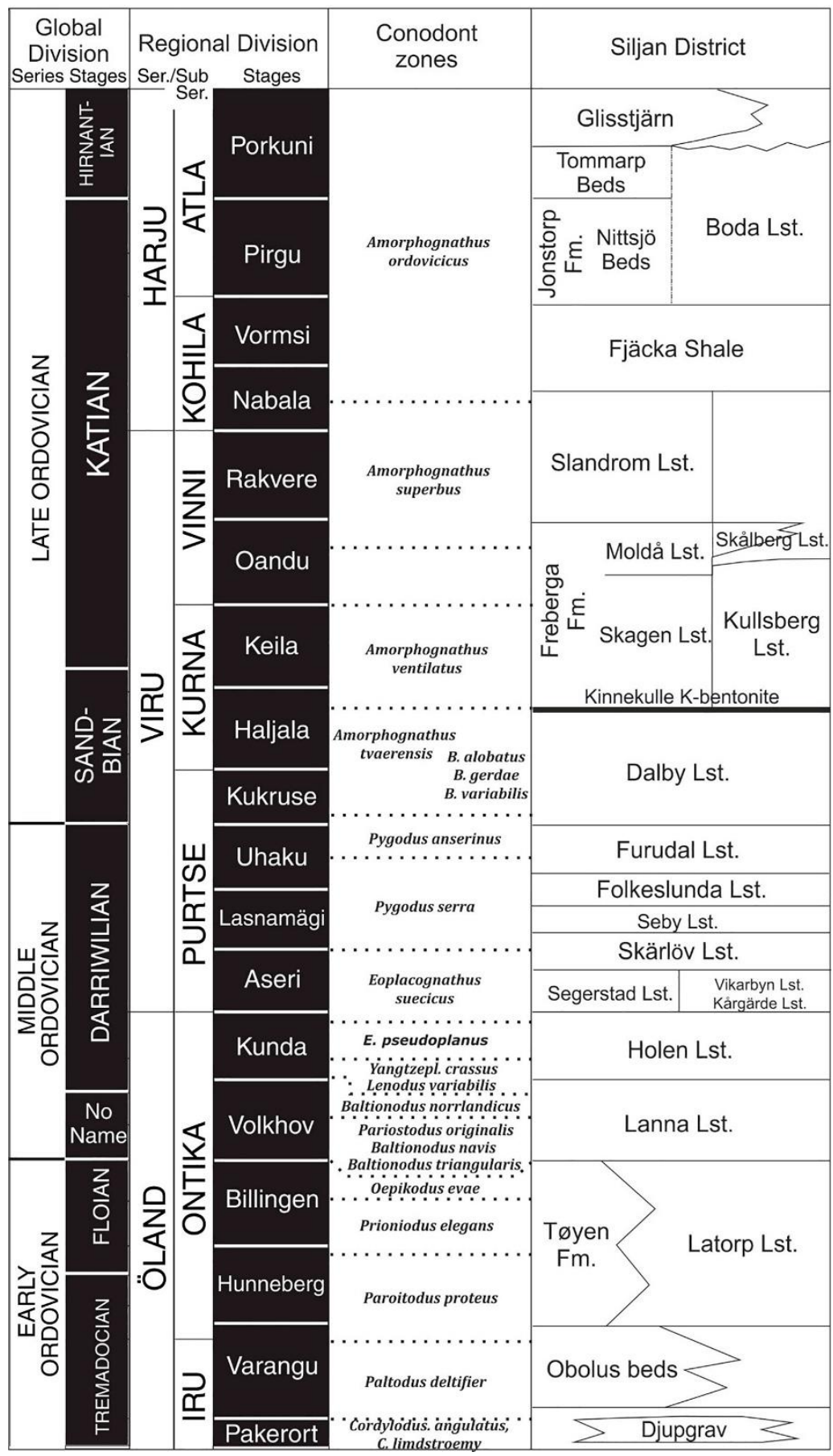

Figure 2. Stratigraphic diagram of the sedimentary succession in the Siljan District (modified from Ebbestad \& Högström 2007 [7]). 


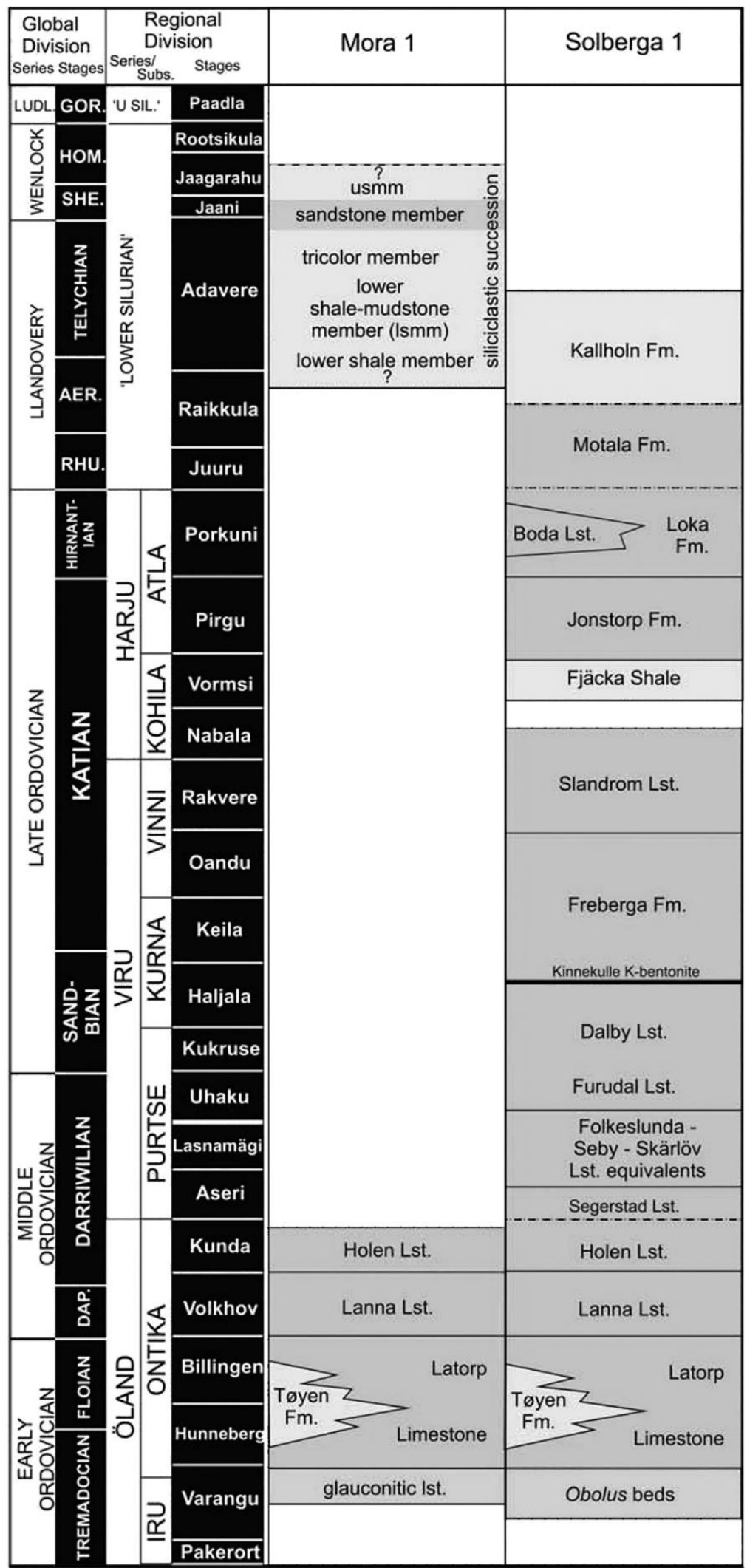

Figure 3. Lithostratigraphic columns of the Mora 1 and Solberga 1 core sections (according to data from Lehnert et al. 2012 [17]). 


\section{Materials and Methods}

The Swedish company Igrene AB drilled the C-C-1 well in the southwestern part of the Siljan Ring nearby the Mora 1 site in 2017 (Fig. 1). The provided core is $602.30 \mathrm{~m}$ long, which includes $373.55 \mathrm{~m}$ of sedimentary and $228.75 \mathrm{~m}$ of basement rock sections. The interval of sedimentary cover ranges from 32.60 to $406.15 \mathrm{~m}$ and the basement section is from 406.15 to $634.90 \mathrm{~m}$.

Detailed petrologic descriptions were performed on 54 sedimentary and 46 basement rock samples as a result of laboratory investigations, which included structure analysis of samples, texture and mineralogical analysis in thin sections.

Structures were defined by visual examination of samples (approximately $5 \times 10 \mathrm{~cm}$ in size) and basic assumptions of rock formation conditions were made. Texture and mineralogical analyses were conducted in thin sections under a polarizing microscope (Axio Imager A2m, Carl Zeiss MicroImaging $\mathrm{GmbH}$ ). The results obtained included the main constituents (minerals and rock fragments), their relations and alteration processes.

To determine the mineralogy of the basement rock four samples of the main petrotypes were analyzed by the X-ray diffraction (XRD) method (RIGAKU, SmartLab, Japan). Table 1 gives the general mineralogy content in percentage for all samples.

Description of fracturing was based on visual estimation of fracture relationships and dip angle combined with analysis of fracture mineralization in thin sections. Fracture dip angle was determined assuming a vertical borehole.

Image analysis was conducted to estimate a possible volume of pore space. Ten samples of basement rocks were chosen for this type of analysis. The study included the following steps:

- determination of main model components based on petrographic description;

- delineation of determined components on photomicrographs as geometrical zones;

- digital analysis of delineated zones in software with percentage results.

The main components include rock matrix, micro-porosity confined to cataclase zones, calcite filling zones (mostly developed along fractures) and open vugs.

Scanning electron microscope (JEOL 6610, Japan) was used to confirm the presence of micro-porosity in the cataclase zones.

Obtained data enables the ratio of open pore space to the whole volume of rock to be estimated, together with the percentages of other important components such as microporosity and calcite filling zones.

The core section was divided into twelve units according to the genetic identity of rocks. Descriptions of units and rock properties are given in the following sections.

\section{Results}

\subsection{Basement section}

The basement section consists of Proterozoic meta-volcanic and meta-sedimentary rocks with a single mafic intrusion (gabbro-dolerite) in the upper part (Fig. 4). Mineralogical changes in rock composition, such as fine-grained sericite and albite neoformation, reveal that the area has gone through the low-grade stage of metamorphism with temperature, presumable up to $200^{\circ} \mathrm{C}[8,19,20]$. However, the rocks often have relict sedimentary structures, such as horizontal and lenticular bedding. Thus, it is possible to suggest that these rocks have been only partially metamorphosed.

The first unit of the basement section (at 555.33 to $634.90 \mathrm{~m}$ depth) consists of albitequartz metasiltstones and metatuff siltstones intercalation. There are some layers of sericite-quartz vitric metatuffs in the lower part of the unit, which probably point out the time of the most active volcanogenic phase. 

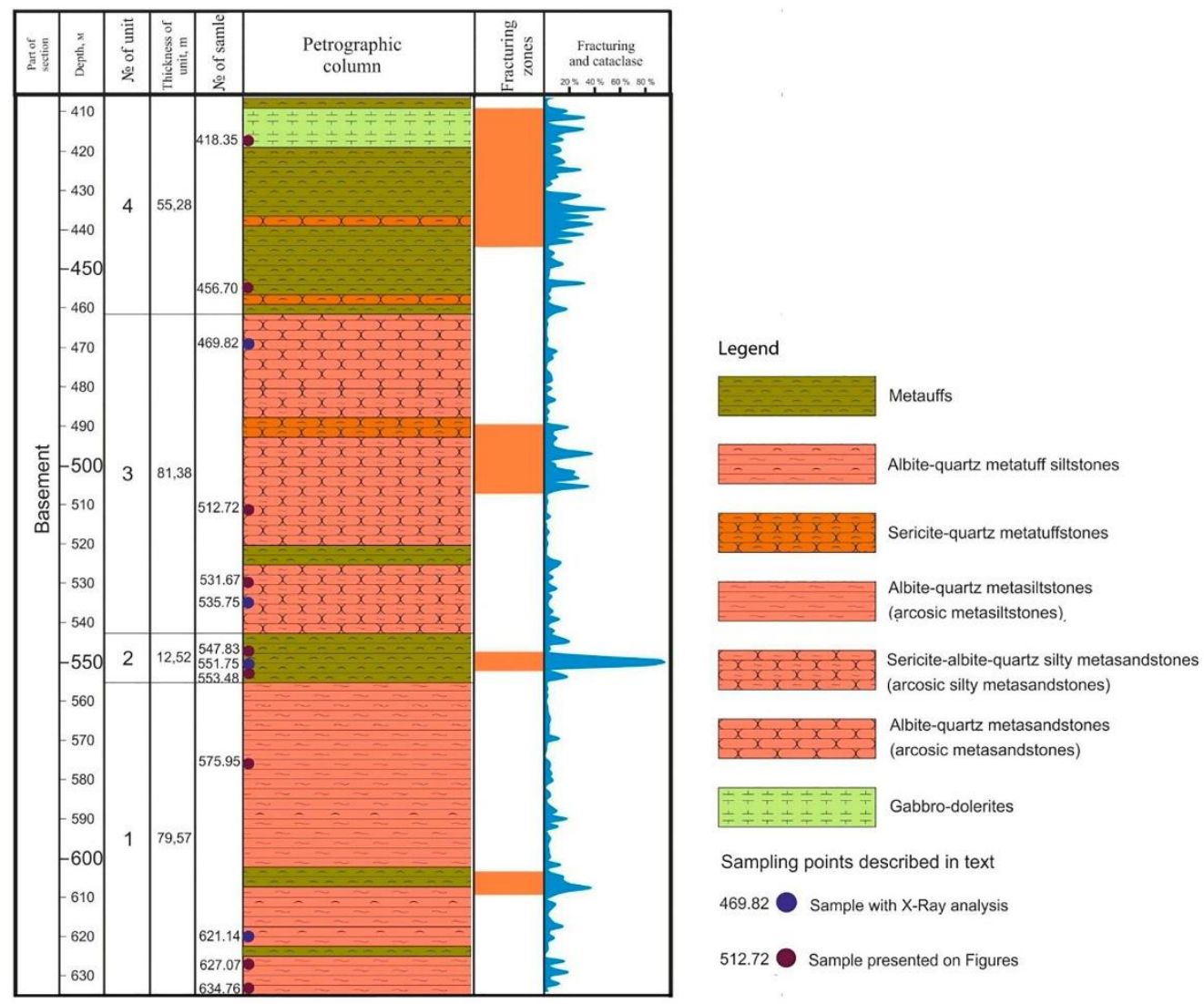

Figure 4. The structure of the basement section.

Albite-quartz metasiltstones (Fig. 5a-c) are prevalent in the unit. The rocks have brown, wine red, dark-gray and gray colors. The structure is massive, spotted, lenticular bedding, in some cases poorly distinguished horizontal bedding. The texture is lepidoblastic and relict psammite-silty.

Mineralogical composition of relict clasts includes quartz (80-85\%), Na-Ca feldspar (10-15\%), K-feldspar (2-3\%), micas - muscovite, biotite (1-2\%), and siliceous rock clasts (1$2 \%)$. Calcitization of some parts of the matrix and chloritization of biotite flakes have been noticed as the result of alteration processes.

Quantitate analysis by XRD was used to calibrate the petrographic investigation in thin sections (Table 1). The analysis was performed on bulk mass and has revealed general mineralogical rock contents.

The next unit ( $2^{\text {nd }}$, at 542.81 to $555.33 \mathrm{~m}$ depth) is represented by a transition from albite-quartz metatuffs to sericite-quartz vitric metatuffs.

Albite-quartz metatuffs (Fig. 5d-f) have reddish and greenish-gray colors. The texture is microgranoblastic and vitric in some parts.

The mineralogical composition: quartz (45-50\%), Na-Ca feldspar (30-35\%), K-feldspar $(5-10 \%)$, mica - muscovite (8-10\%), and calcite, dolomite, chlorite (Table 1).

Sericite-quartz vitric metatuffs (Fig. 5g-i) have greenish-gray and light-green colors. The texture is vitric.

The mineralogical composition: quartz (70-75\%), Na-Ca feldspar - albite (15-20\%), mica - muscovite (10-12\%), K-feldspar (1-3\%), and calcite.

The majority of the rock matrix is volcanic glass, which has been almost completely replaced by sericite and calcite in some parts. 
Table 1. The result of quantitative XRD-analysis of four basement rock samples (bulk mass).

\begin{tabular}{|c|c|c|c|c|c|}
\hline \multirow[b]{2}{*}{ Phase name } & \multirow[b]{2}{*}{ Formula* } & \multicolumn{4}{|c|}{ Content $(\%)$} \\
\hline & & $\begin{array}{c}\text { Albite-quartz } \\
\text { metasiltstone } \\
621.14 \mathrm{~m} \\
\text { (1st unit) }\end{array}$ & $\begin{array}{c}\text { Albite- } \\
\text { quartz } \\
\text { metatuff } \\
551.75 \mathrm{~m} \\
\text { (2nd unit) }\end{array}$ & $\begin{array}{l}\text { Sericite-albite- } \\
\text { quartz silty } \\
\text { metasandstone } \\
535.75 \mathrm{~m} \\
\text { (3hd unit) }\end{array}$ & $\begin{array}{c}\text { Albite-quartz } \\
\text { metasandstone } \\
469.82 \mathrm{~m} \\
\text { (3rd unit) }\end{array}$ \\
\hline Quartz & $\mathrm{SiO}_{2}$ & 57.5 & 45.9 & 48.1 & 47.2 \\
\hline $\begin{array}{c}\text { Na-Ca feldspar } \\
\text { (Albite) }\end{array}$ & $(\mathrm{Na} .98 \mathrm{Ca} .02)\left(\mathrm{Si}_{2.98} \mathrm{Al}_{1.02}\right) \mathrm{O}_{8}$ & 23.6 & 35.2 & 25.6 & 31.3 \\
\hline $\begin{array}{l}\text { K-feldspar } \\
\text { (Orthoclase } \\
\text {-Microcline) }\end{array}$ & $\mathrm{K}\left[\mathrm{AlSi}_{3} \mathrm{O}_{8}\right]$ & 7.5 & 8.5 & 19.2 & 6.9 \\
\hline Muscovite-2M1 & $(\mathrm{K}, \mathrm{Na}) \mathrm{Al}_{2}(\mathrm{Si}, \mathrm{Al})_{4} \mathrm{O}_{10}(\mathrm{OH})_{2}$ & 6.0 & 8.1 & 6.9 & 7.6 \\
\hline Calcite & $\mathrm{Ca}\left(\mathrm{CO}_{3}\right)$ & 5.0 & 1.3 & 0.2 & 6.5 \\
\hline Pyrite & $\mathrm{FeS}_{2}$ & 0.2 & & & \\
\hline Chlorite & $\mathrm{Si}_{3} \mathrm{Al}_{1.2} \mathrm{Mg}_{5} \mathrm{Fe} .1 \mathrm{Cr}_{.7} \mathrm{O}_{18} \mathrm{H}_{7.9}$ & 0.2 & 0.5 & & 0.2 \\
\hline Dolomite & $\mathrm{Ca}\left(\mathrm{Ca} 0.07 \mathrm{Mg}_{0.93}\right)\left(\mathrm{CO}_{3}\right)_{2}$ & & 0.5 & & \\
\hline Anhydrite & $\mathrm{CaSO}_{4}$ & & & & 0.3 \\
\hline
\end{tabular}

${ }^{*}$ Chemical formula from the database

The $3^{\text {rd }}$ unit (at 461.43 to $542.81 \mathrm{~m}$ depth) is represented by a transition from sericitealbite-quartz silty metasandstones to albite-quartz metasandstones. There are layers of sericite-quartz vitric metatuffs in the lower part and sericite-quartz metatuffstones in the upper part of the unit.

Sericite-albite-quartz silty metasandstones (Fig. 6a-c, Table 1) are characterized by their brown color and massive structure together with poorly distinguished bedding in some parts. The texture is silty-psammite.

The mineralogical composition: quartz (80-85\%), Na-Ca feldspar -albite (10-12\%), Kfeldspar (3-5\%), mica - muscovite (1-2\%). Calcite and sericite replace the rock matrix in some parts. 
a
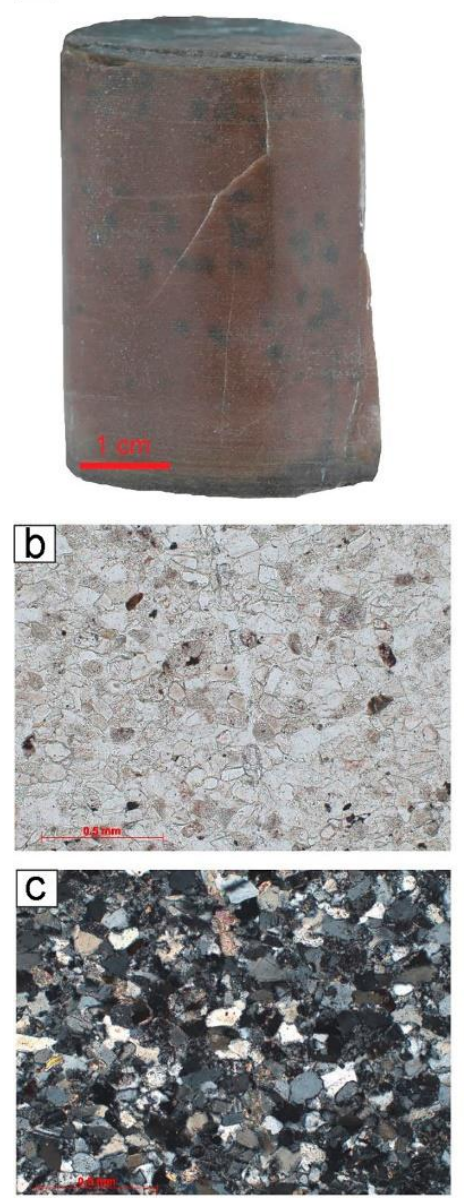

d]
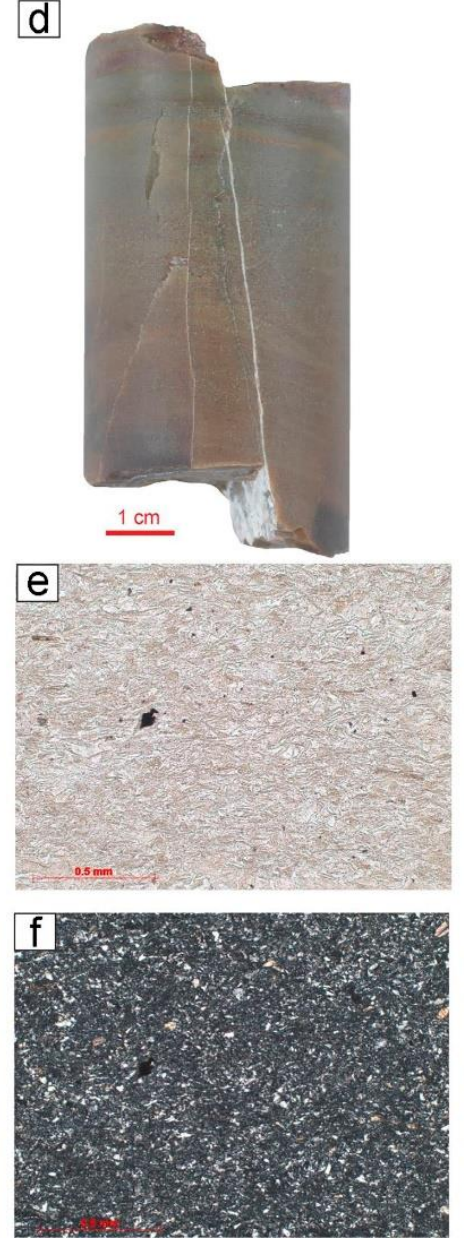

g
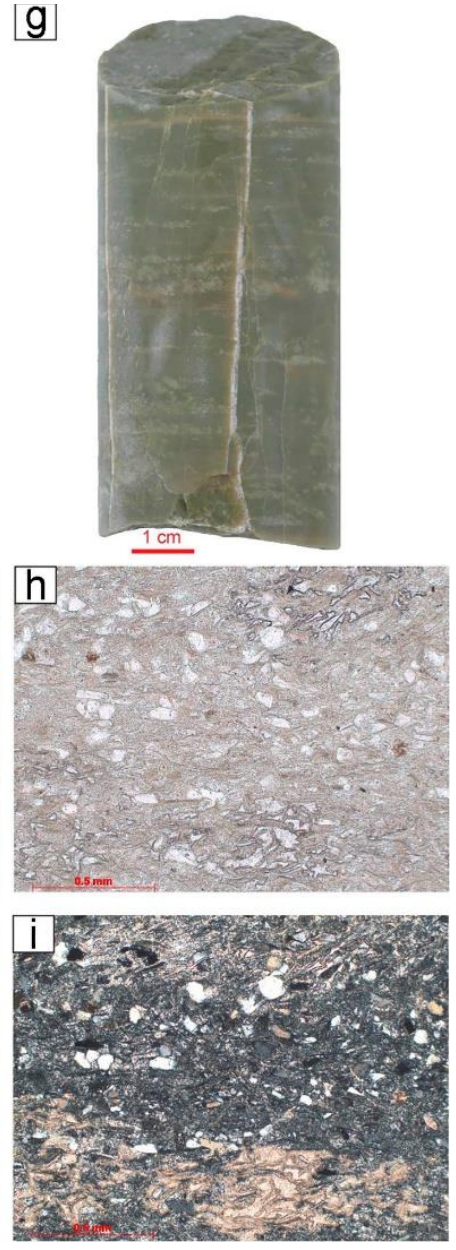

Figure 5. The rock samples from the lower part of basement section: $(\mathbf{a}, \mathbf{d}, \mathbf{g})$ - sample photos; $b, e$, (h) - thin section photos in plane-polarized light; (c, f, i) - thin section photos with crossed polars (magnification 10x). (a) Spotted structure and poorly distinguished horizontal bedding in albitequartz metasiltstones. (b) Psammite-silty texture. (c) quartz prevalence. Sample depth $627.07 \mathrm{~m}\left(1^{\text {st }}\right.$ unit). (d) Horizontal bedding in albite-quartz metatuffs. (e) Micro-granoblastic and vitric texture.

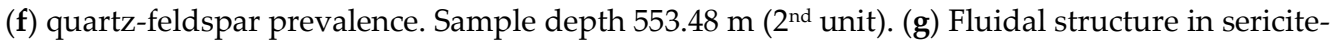
quartz vitric metatuffs. (h) Quartz grains in vitric mass. (i) Calcite zones in upper and lower parts of the section. Sample depth $547.83 \mathrm{~m}$ ( $2^{\text {nd }}$ unit).

Albite-quartz metasandstones (Fig. 6d-f, Table 1) have characteristics similar to sericite-albite-quartz silty metasandstones: brown color and massive structure together with poorly distinguished bedding in some parts. The texture is granoblastic and relict psammitic.

The mineralogical composition: quartz (80-85\%), Na-Ca feldspar - albite (10-15\%), Kfeldspar (2-3\%), mica - muscovite (1-2\%), siliceous clasts (1-2\%), calcite and chlorite. Sericite-feldspar mass fills intergrain space.

The $4^{\text {th }}$ unit (at 406.15 to $461.43 \mathrm{~m}$ depth) consists of sericite-quartz metatuffstones, sericite-quartz vitric metatuffs and albite-quartz metatuffs intercalation. The mafic intrusion (gabbro-dolerite) occurs at a depth of 409.65 to $422.40 \mathrm{~m}$.

Gabbro-dolerite (Fig. 6g-i) is black with red and light gray spots in some parts. The structure is massive and spotted. The texture is poikilite-ophitic and ophitic with micropegmatitic elements.

The mineralogical composition: Na-Ca feldspar - labradorite (55-60\%), clinopyroxene $(10-15 \%)$, orthopyroxene (5-10\%), olivine (5-7\%), micro-pegmatite (5-10\%), mica -biotite $(3-5 \%)$, quartz $(2-3 \%)$, individual amphibole grains and volcanic glass clasts; chlorite, sericite, iron hydroxide. 
a
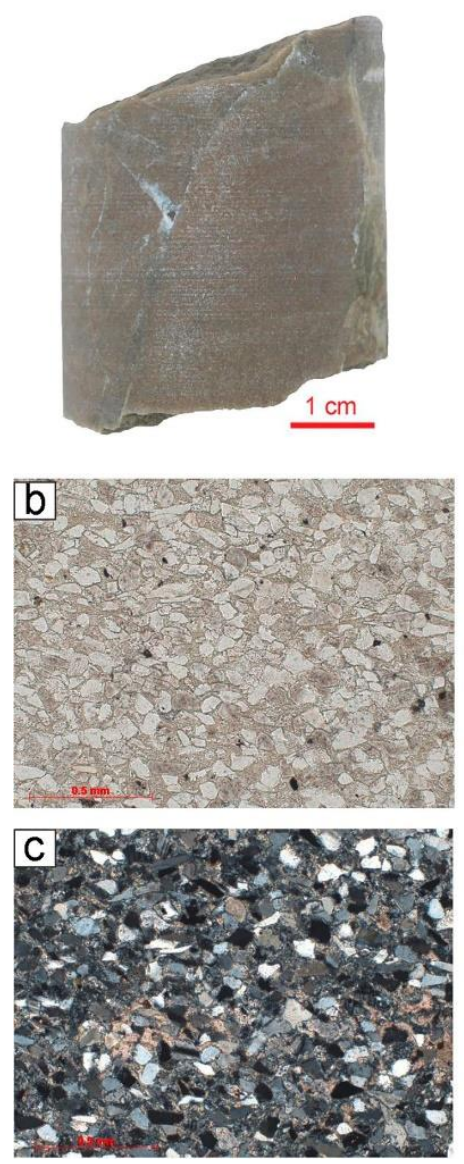

d
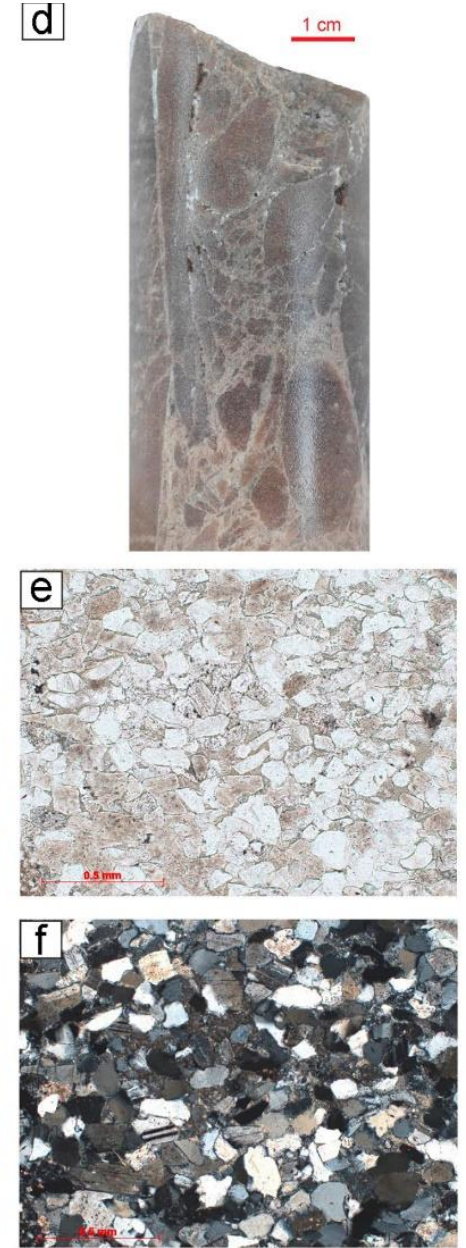

g
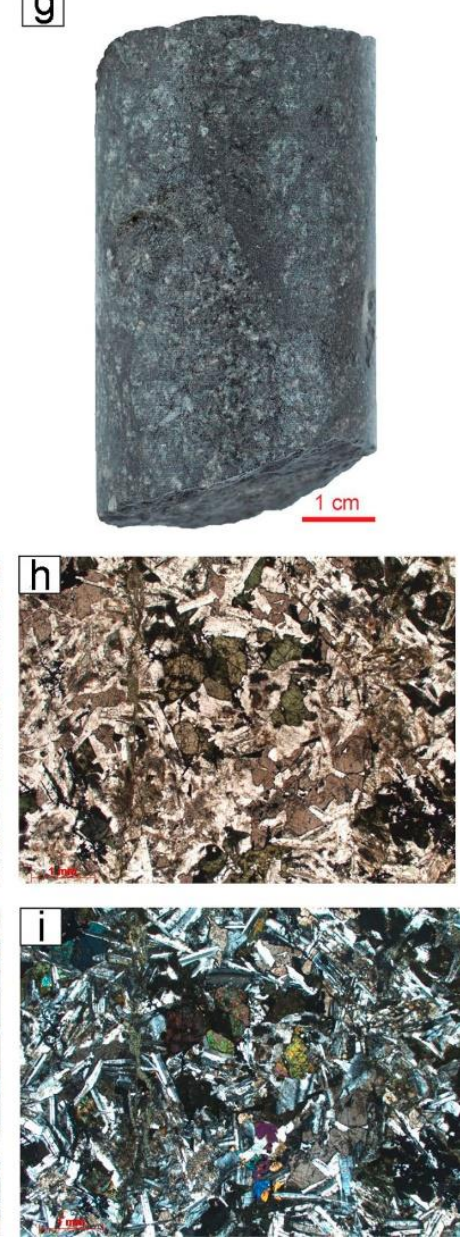

Figure 6. The rock samples from the upper part of basement section: $(\mathbf{a}, \mathbf{d}, \mathbf{g})$ - sample photos; b, e, (h) - thin section photos in plane-polarized light. $(\mathbf{c}, \mathbf{f}, \mathbf{i})$ - thin section photos with crossed polars (magnification 10x, $\mathbf{i}-2.5 \mathrm{x}$ ). (a) Massive structure in sericite-albite-quartz silty metasandstones. (b) Silty-psammite texture. (c) Quartz prevalence. Spots of calcite in gray mass. Sample depth $512.72 \mathrm{~m}$ (3 ${ }^{\text {rd }}$ unit). (d) Cataclastic zone in albite-quartz metasandstones. (e) Relict psammite tex-

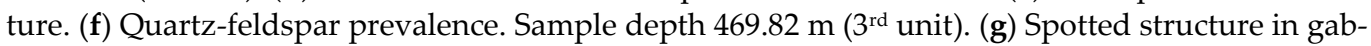
bro-dolerite. (h) poikilite-ophitic texture; i prevalence of Na-Ca feldspar and pyroxenes. Sample depth $418.35 \mathrm{~m}$ (4th unit).

\subsection{Sedimentary cover section}

The sedimentary section consists of Paleozoic rocks. Comparison with the results of previous studies and lithological descriptions in the stratigraphic schemes $[3,7,17,18]$ allows us to conclude that sedimentary layers represent Upper Ordovician and Silurian sediments, and have disturbed stratigraphic relations (Fig. 7). 

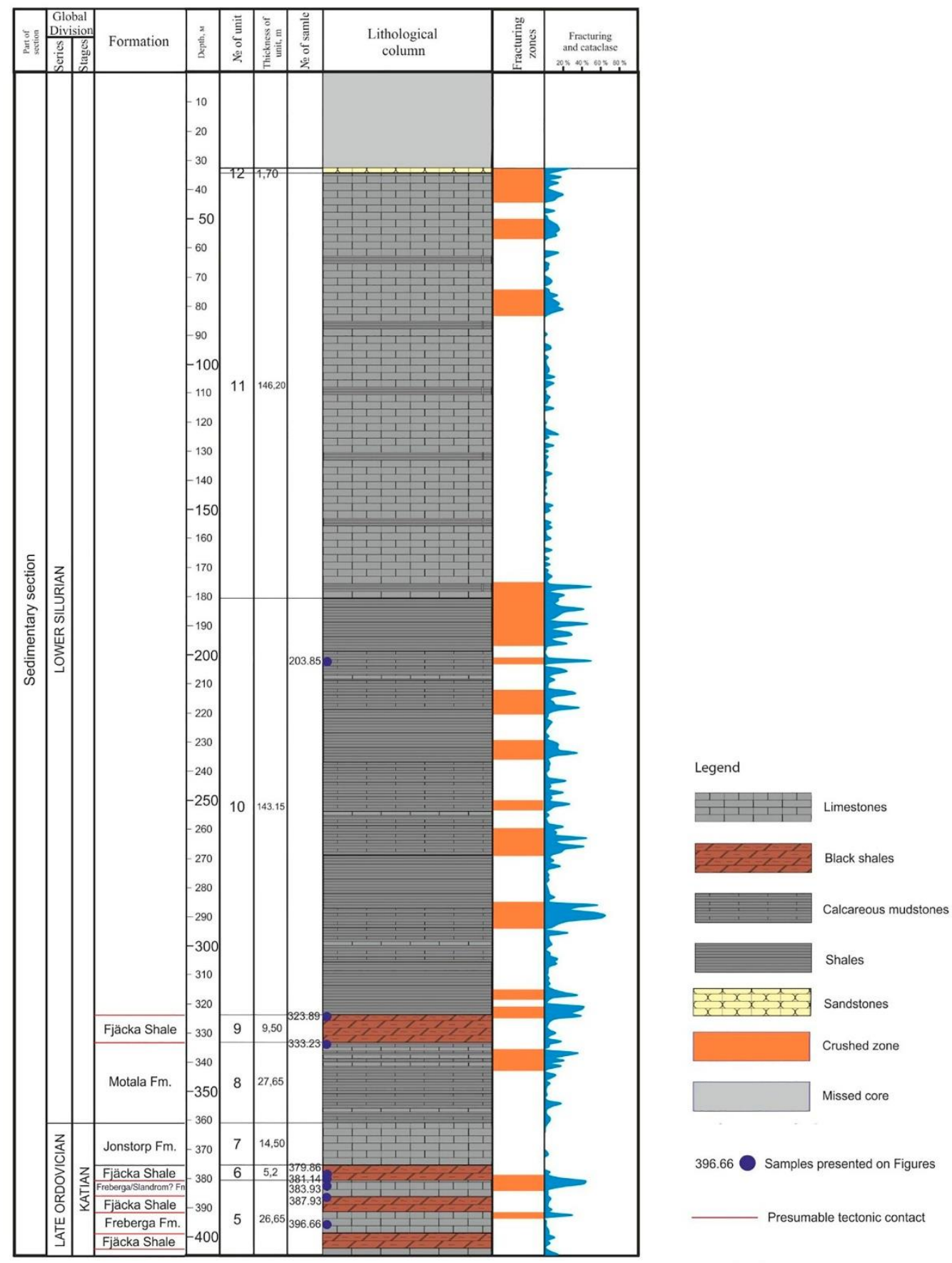

Figure 7. The structure of sedimentary section with preliminary lithostratigraphy

The $5^{\text {th }}$ unit (at 380.50 to $406.15 \mathrm{~m}$ depth) is represented by the intercalation of black shales and wackestones. The thickness of black shale layers varies from 0.2 to $9.0 \mathrm{~m}$, the thickness of wackestones is $0.3-2.0 \mathrm{~m}$.

Wackestones (Fig. 8a-d) are shades of gray in color and intercalate with dark-gray clayey limestones and calcareous mudstones. Fossils are represented by debris made up of trilobite, hyolithid, bryozoans, pelmatozoans, ostracode, brachiopode shells, and, rarely, charophyceae remains.

Black shales (Fig. 8e-f) are dark-brown to black and are predominantly massive; sometimes they are thin laminated. They contain a quartz silt-size admixture of up to $25 \%$ and ca. $15-30 \%$ of dispersed organic matter. 
A comparison with lithological descriptions published in previous studies $[3,7,17,18]$ allows the suggestion that wackestones belong to Freberga and Slandrom formations (Upper Ordovician) and black shales intervals are Fjäcka Shale layers.
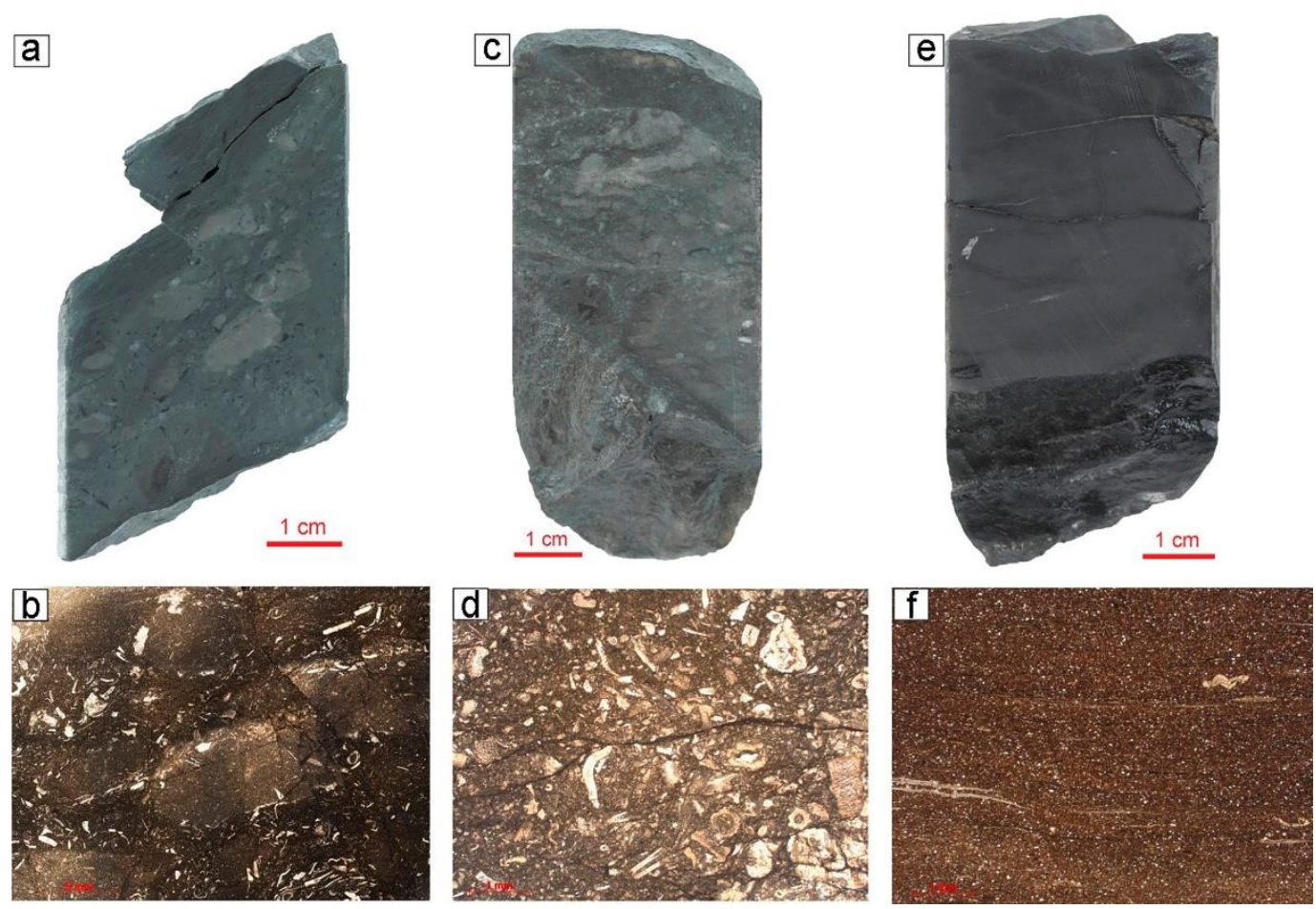

Figure 8. The rock samples from the sedimentary cover section: $(\mathbf{a}, \mathbf{c}, \mathbf{e})$ - sample potos; $(\mathbf{b}, \mathbf{d}, \mathbf{f})-$ thin section photos in plane-polarized light (magnification 2.5x). (a) spotted structure and intraclasts in gray wackestone. Shifting of rock parts along inclined fracture. (b) detritus and cataclastic zone in wackestone. Sample depth $396.66 \mathrm{~m}$ (5 $5^{\text {th }}$ unit). (c) spotted structure in gray wackestone. (d) trilobites, briozoans clasts and charophyceae remains. Subhorizontal fracture. Sample depth 387.93 $\mathrm{m}$ (5th unit). (e) massive structure in black shale. (f) silty black shale. Single debris of brachiopods. Brown color due to dispersed organic matter. Sample depth $379.86 \mathrm{~m}$ (6 $6^{\text {th }}$ unit).

Taking into account the features such as the sharp contact with underlying basement rocks and layers in between, slump structures and evidence of bedding inclination (up to 45 degrees) - due to tectonic displacement - it is likely that those layers are of allochthonous origin.

The next two units, $6^{\text {th }}$ and 7 th (at 360.80 to $380.50 \mathrm{~m}$ depth), are represented by layers of black shales and wackestones respectively. The change from black shales to wackestones is sedimentary transitional. However, this interval of wackestones is noticeably different from the underlying rocks. The structures are predominantly nodular; layering is horizontal and the upper part of the wackestone unit has a reddish color (Fig. 9). It has been possible to interpret this as evidence of a transition from Fjäcka Shale to Jonstorp Formation (Upper Ordovicican, Katian).

The $8^{\text {th }}$ unit (at 333.15 to $360.80 \mathrm{~m}$ depth) is represented by calcareous mudstones with nodules of clayey limestones. The contact with the underlying rocks is sedimentary transitional. This evidence, together with structure-texture rock characteristics, enable us to consider this unit to be a layer of Lower Silurian sediments, Motala Formation.

Next, the $9^{\text {th }}$ unit (at 323.65 to $333.15 \mathrm{~m}$ depth) consists of black shales and it has been suggested that slices of Fjäcka Shale were moved due tectonic activity. The findings of recrystallized limestone with extension fractures (Fig. 10) at the lower boundary and claycarbonate breccia (Fig. 11) at the upper boundary of the unit may be taken as evidence of that movement. 


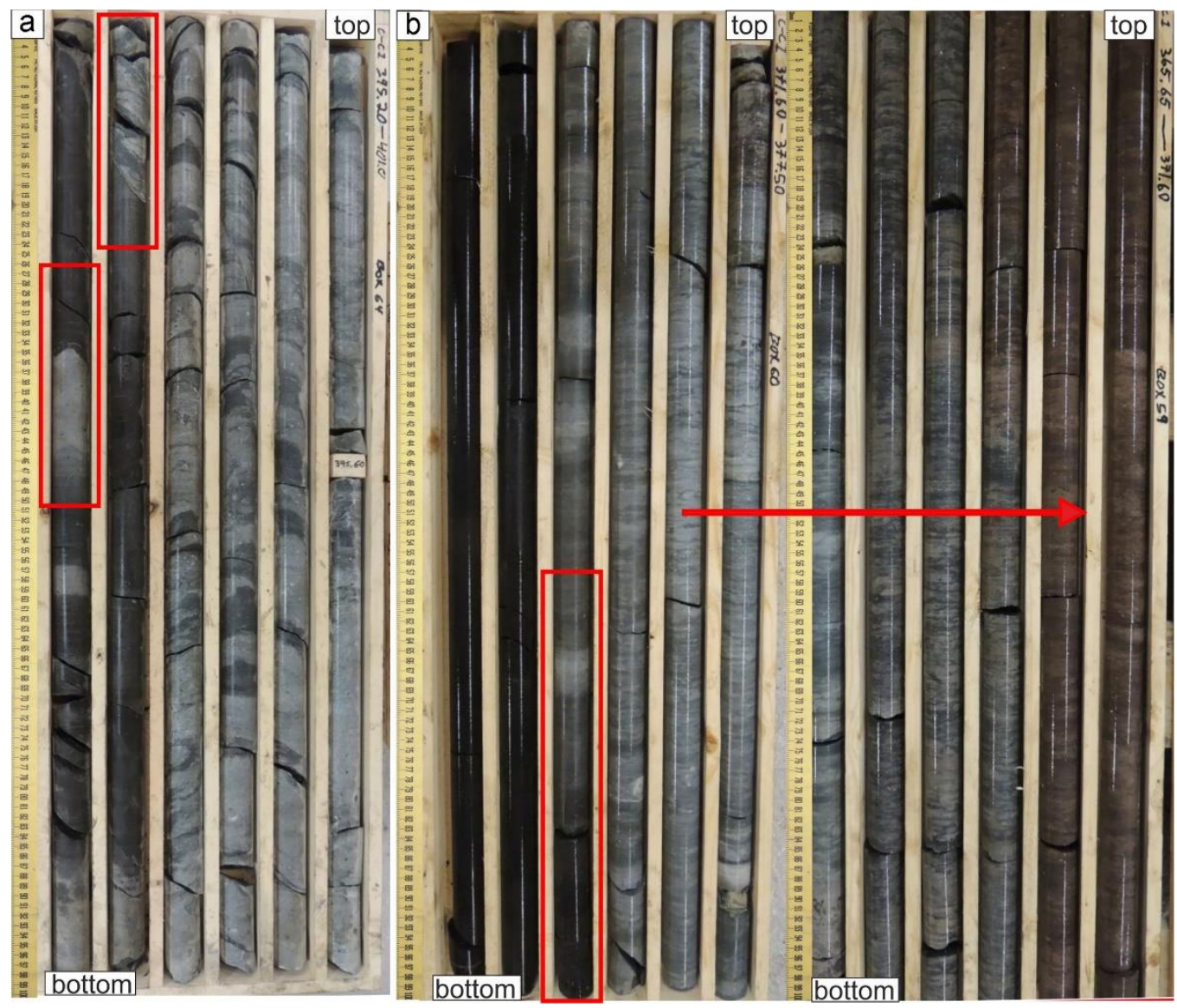

Figure 9. Core photo: (a) sharp contact between black shale and wackestone layers, slump structures in wackestones. Depth interval 395.20-401.00 $\mathrm{m}$ ( $5^{\text {th }}$ unit). (b) Sedimentary contact between black shale and wackestone layers (red box). Transition from greenish-gray to reddish wackestones (red arrow). Depth interval 365.65-377.50 m (6-7 th $^{\text {thit). }}$
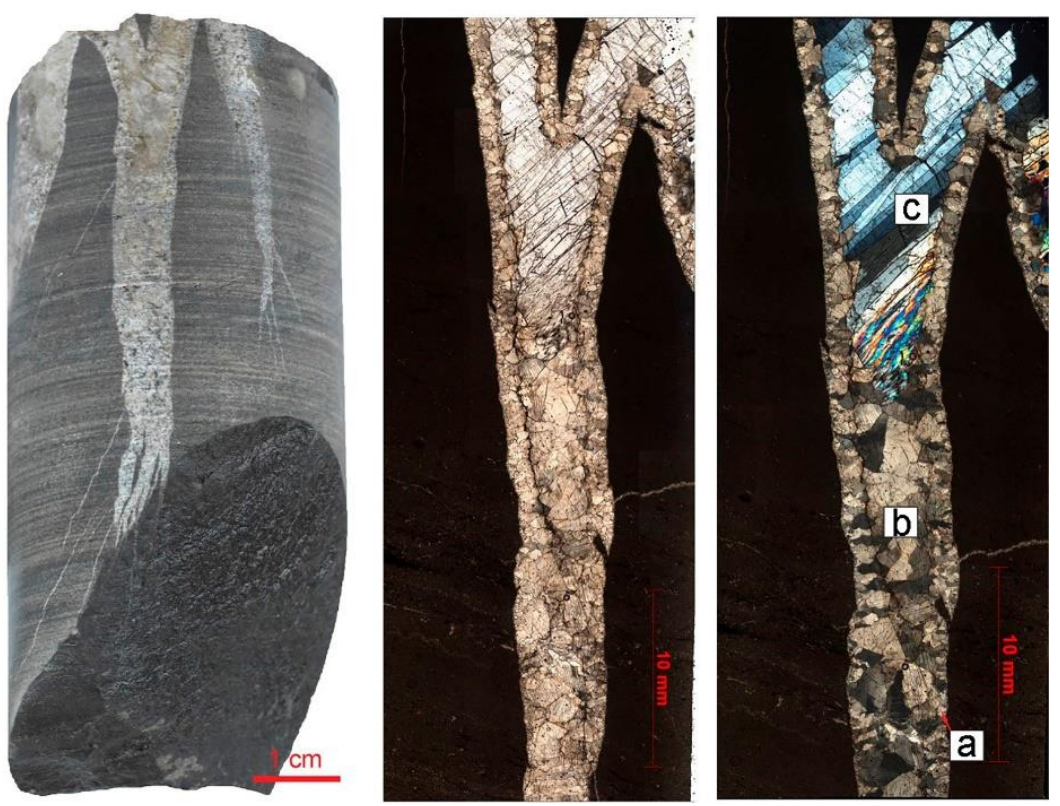

Figure 10. Extension fracture in limestone. Sample photo - left. Three stage fracture filling: with calcite (a-b) and anhydrite (c). Photo of thin section in plane-polarized light - middle, and crossed polars - right. Sample depth $333.23 \mathrm{~m}$ ( $8^{\text {th }}$ unit). 


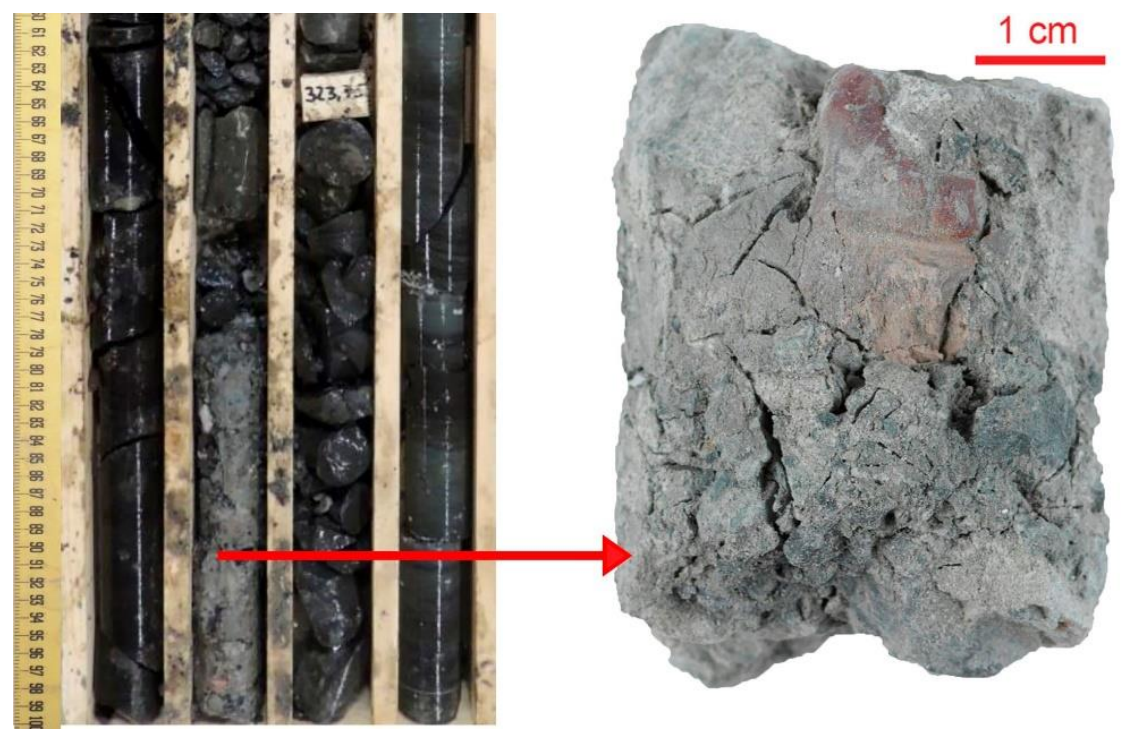

Figure 11. Clay-carbonate tectonic breccia at the upper boundary of black shale units. Core photo left. Sample photo - right. Sample depth $323.89 \mathrm{~m}$ ( $8^{\text {th }}$ unit).

The $10^{\text {th }}$ unit (at 180.50 to $323.65 \mathrm{~m}$ depth) is represented by an intercalation of calcareous mudstones (Fig. 12) and shales with occasional layers of clayey limestone. Evidence of crushed zones with rock alteration (cataclase, recrystallization) probably reflects tectonic movements along fault planes. However, due to the lithological homogeneity of the unit it is difficult to recognize any stratigraphic differences. Therefore, the whole interval has only been considered to be Lower Silurian deposits.
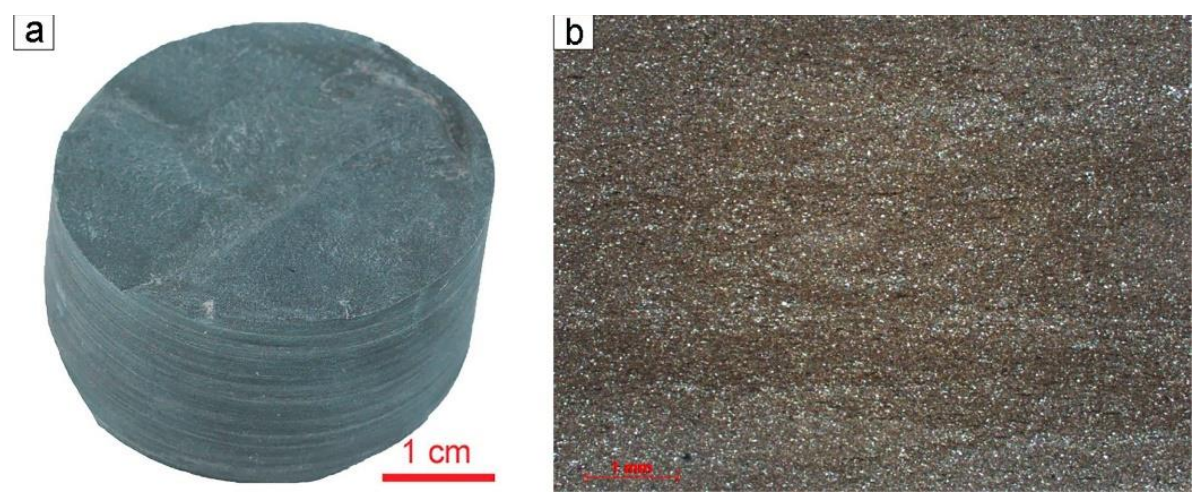

Figure 12. (a) Calcareous mudstone. Sample photo. (b) Silt-pelitic texture. Thin section photo (plane-polarized light). Sample depth $203.85 \mathrm{~m}$ (10 $10^{\text {th }}$ unit).

The $11^{\text {th }}$ unit (at 34.30 to $180.50 \mathrm{~m}$ depth) consists of predominantly clayey limestones. Structures are nodular and spotted. The upper part of the interval at a depth 34.30 to 77.60 $\mathrm{m}$ has gray, greenish-gray and reddish colors that probably correspond to the tricolour member of Lower Silurian deposits (Fig. 13).

A layer of fine to medium-grained light-gray sandstone completes the sedimentary section $-12^{\text {th }}$ unit (at 32.60 to $34.30 \mathrm{~m}$ depth). Taking previous studies and regional stratigraphy schemes into account allows considering this layer as the beginning of a new Silurian sedimentary cycle.

In summary, these results suggest depositional environments and cyclic character of sedimentary sequences. Although the unit boundaries often are not sedimentary transitional, the conclusion can nevertheless be drawn - from the structures, textures and composition of the rocks - that the majority of the sedimentary deposits were formed in the sublittoral zone. Evidence to particularly support this is the high clay content (up to 10\%) in limestones and the prevalence of such fossils as trilobite, hyolithid, and bryozoans. The 
units consist of black and other shales reveal a maximum of basin depth established with the lowest hydrodynamic activity and anoxic conditions. Only the upper part of the section (Lower Silurian sediments) shows the regressive trend that probably ends with an unconformity, and a new cycle of Silurian clastic deposition starting afterwards.

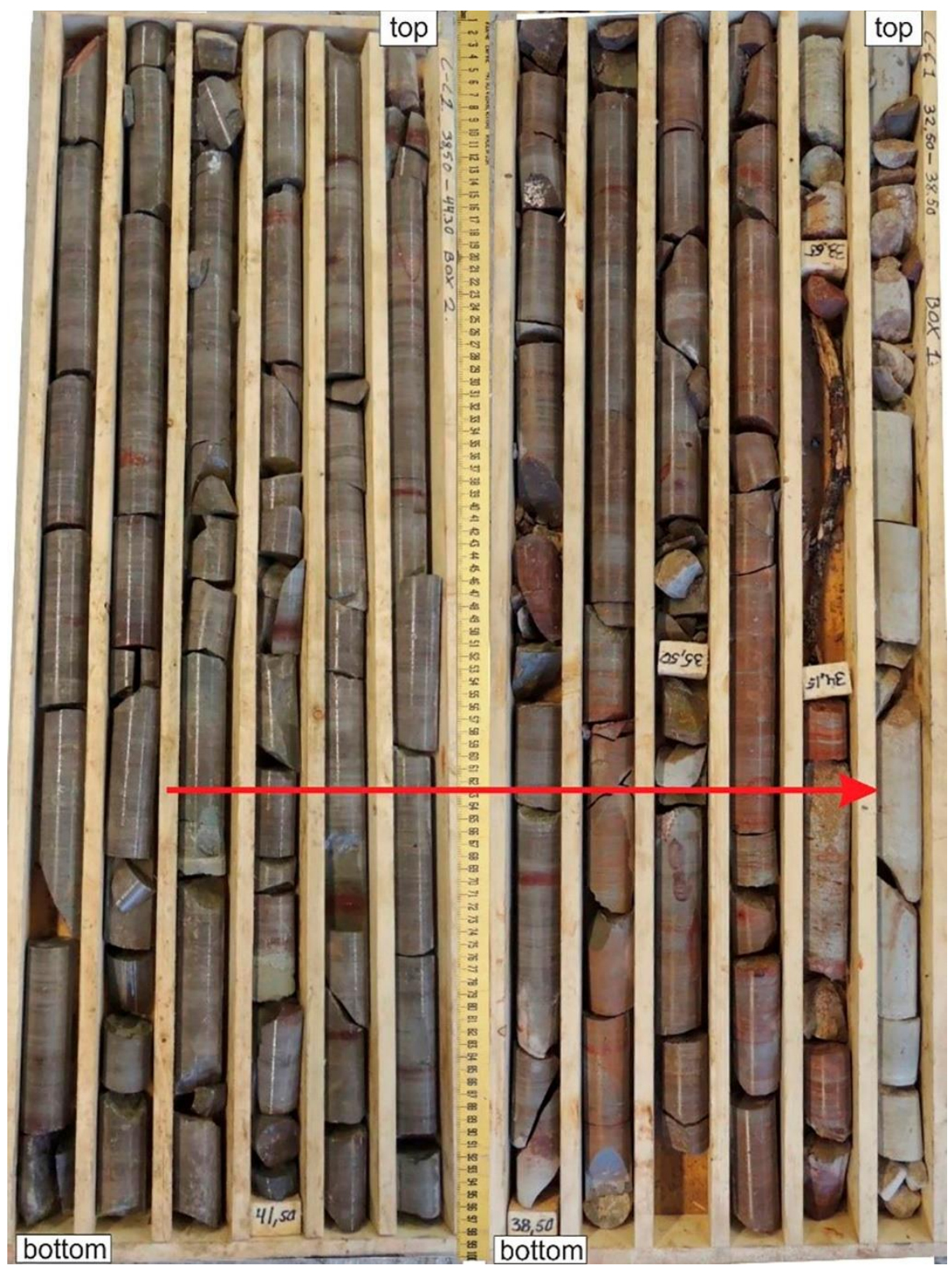

Figure 13. Core photo. Transition from greenish-gray and reddish clayey limestones to light-gray sandstones. Depth interval 32.60-44.70 m.

\subsection{Fracturing and pore space characteristics}

\subsubsection{Fracturing}

Disjunctive deformations are traced throughout the whole section in sedimentary units as well as in the basement rocks. In the basement section, near vertical and steeply inclined fractures (20-30 degrees) are prevalent (Fig. 14a). In the sedimentary section, thin fractures often form chaotic networks and attenuate on cm scale (Fig. 14b).

Detailed petrologic studies allowed recognition of four fracture generations that probably correspond to four tectonic activation stages. In basement rocks, all stages are defined completely with thin section investigations, and only two of them are recognized in sedimentary rocks. 
The sequence of mineral filling is the basis for fracturing stage recognition (Fig. 15). The first stage is characterized by quartz mineralization along fracture sides. Quartz crystals often have a prismatic shape and size up to $1 \mathrm{~mm}$ that probably corresponds to a primary fracture aperture.

During the second stage, the fractures were filled with calcite. Calcite often corrodes quartz crystals and reaches a size of up to $4 \mathrm{~mm}$. Fractures with calcite mineralization are recognized throughout whole basement section apart from the gabbro-dolerite intrusion.

The third generation is traced by cataclastic filling with crushed rock mass, calcite, and quartz grains, and relates to a phase of tectonic reactivation.

In the sedimentary rocks, the third generation developed as cataclastic zones and individual fractures with clay-carbonate filling (Fig. 16).

The fourth generation is traced in sedimentary rocks as well as basement rocks and is represented by tiny extensive fractures sometimes open to $1 \mathrm{~mm}$ width. These fractures cut across all those from previous generations, and have displacement along its direction (Fig. 17).
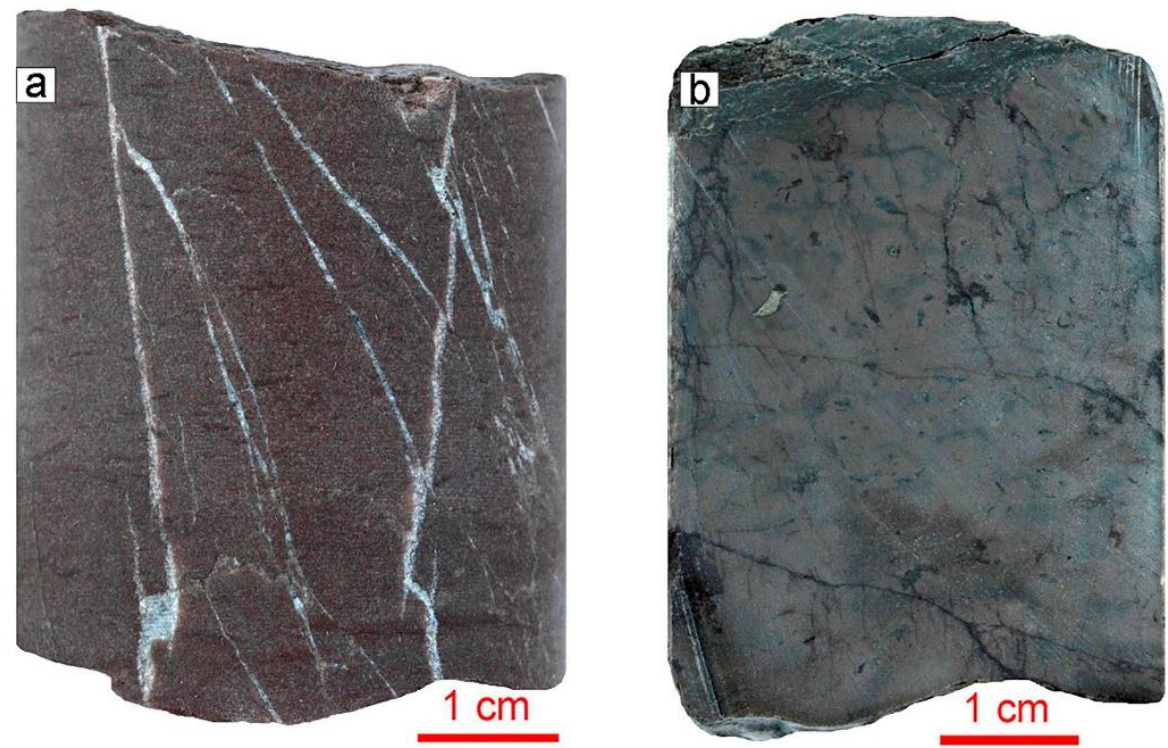

Figure 14. Sample photos. (a) Albite-quartz metasiltstone. Near vertical and steeply inclined fracture filled with calcite. Sample depth $575.95 \mathrm{~m}$ ( $1^{\text {st }}$ unit). (b) Clayey limestone. Network of fine fractures. Sample depth $381.14 \mathrm{~m}$ (5 $5^{\text {th }}$ unit).
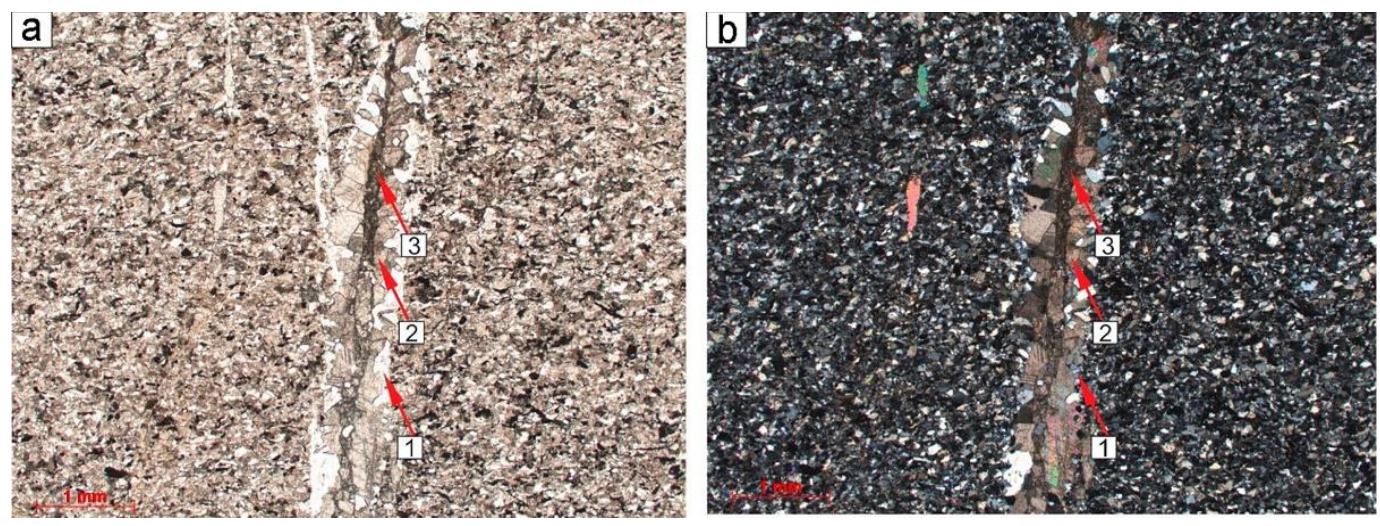

Figure 15. Albite-quartz metasiltstone. Photo of thin section in plane-polarized light (a) and crossed polars (b). Three generations of fractures with: 1 - quartz filling, 2 - calcite, 3 - cataclasis material. Sample depth $634.76 \mathrm{~m}$ (1 $1^{\text {st }}$ unit). 

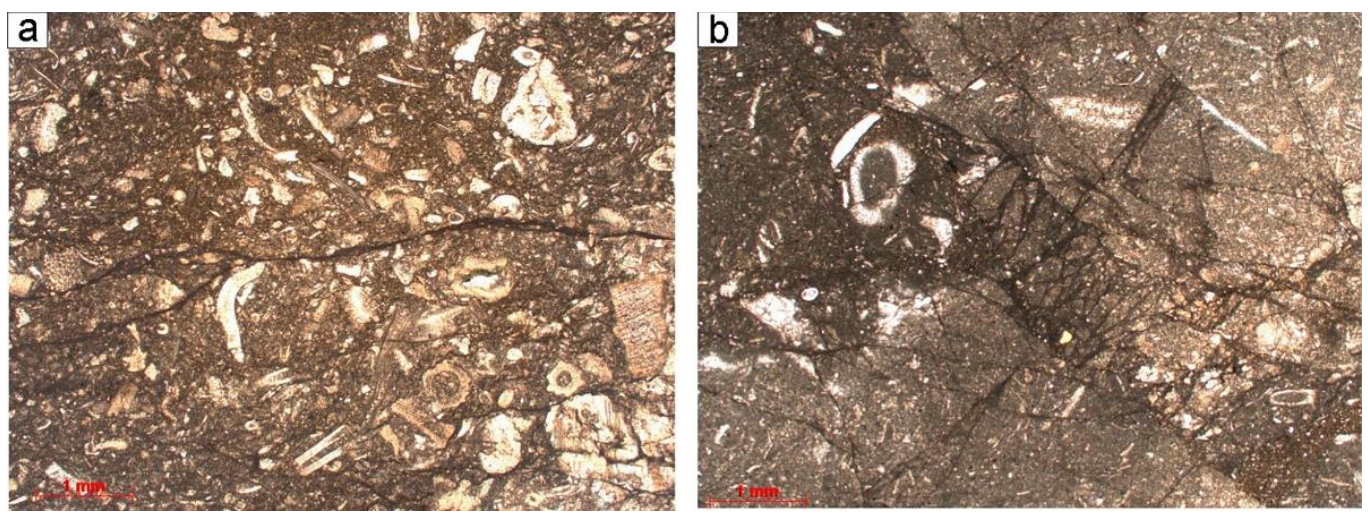

Figure 16. Wackestones. Photo of thin section in plane-polarized light. (a) Individual fracture with clay filling. Sample depth $383.93 \mathrm{~m}$ (5 $5^{\text {th }}$ unit). (b) Cataclastic zone with clay-carbonate filling. Sample depth $396.66 \mathrm{~m}$ ( $5^{\text {th }}$ unit)
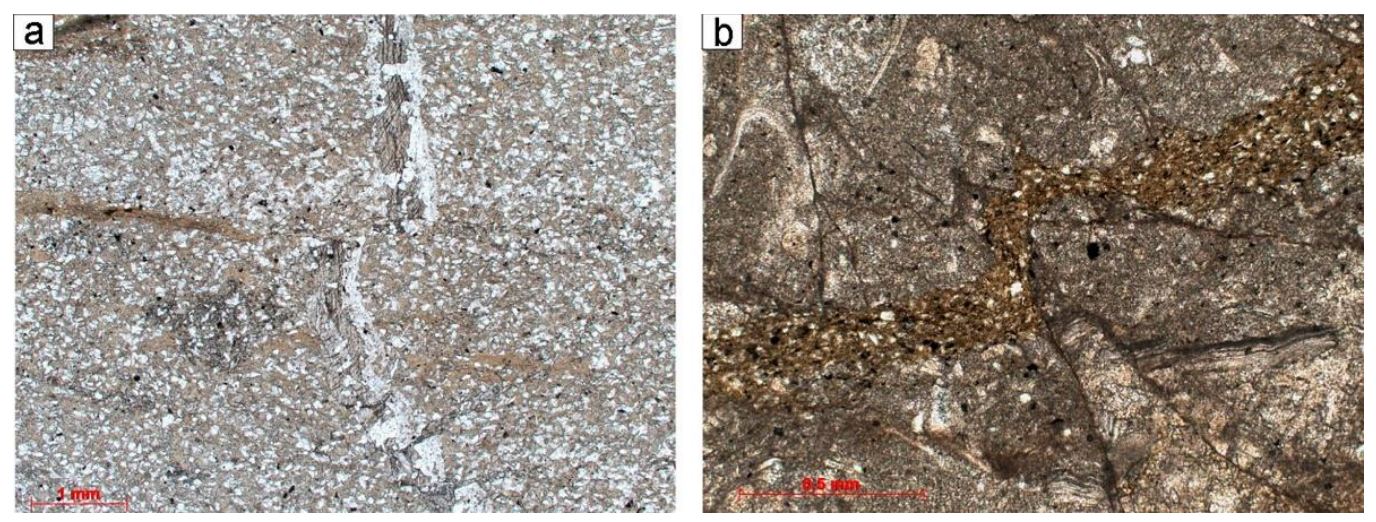

Figure 17. Displacement along direction of third generation fractures. Photo of thin section in plane-polarized light. (a) Sericite-quartz metatuffstone. Sample depth $456.70 \mathrm{~m}$ ( $4^{\text {th }}$ unit). (b) Wackestone. Sample depth $396.66 \mathrm{~m}$ (5 $5^{\text {th }}$ unit).

\subsubsection{Pore space characteristics}

As a result of detailed investigations, a valuable amount of pore space was found only in basement rocks. It is confined to fractures in albite-quartz metasandstones and sericite albite-quartz silty metasandstones.

In sedimentary rocks, the individual evidence of micro-pore space with bituminous filling was established in cataclastic zones (Fig. 18a). In some cases, the bituminous filling is confined to individual vugs with calcite mineralization (Fig. 18b).

The total volume of open pore space in the basement rock includes slit-shaped vugs along fractures, and micro-porosity developed in cataclastic zones. The size of micropores ranges from 0,3 to $12 \mu \mathrm{m}$. (Fig. 19).

"Image analysis" for 10 cylindrical core samples were used to estimate the ratio of open pore space and micro-porosity zones to the whole volume of rock. Based on petrologic description, four macro-components were selected:

- rock matrix;

- micro-porosity confined to cataclase zones;

- calcite filling zones;

- open vugs.

The cataclase and calcite filling zones have been mostly developed along the fractures.

The segments of each component were marked with different colors. Same-color segments form macro-components. Component images were converted into a binary format, 
where component pixels were labeled by units, and the remaining pixels were zeros. The binary results were divided into geometry segments by program processing.
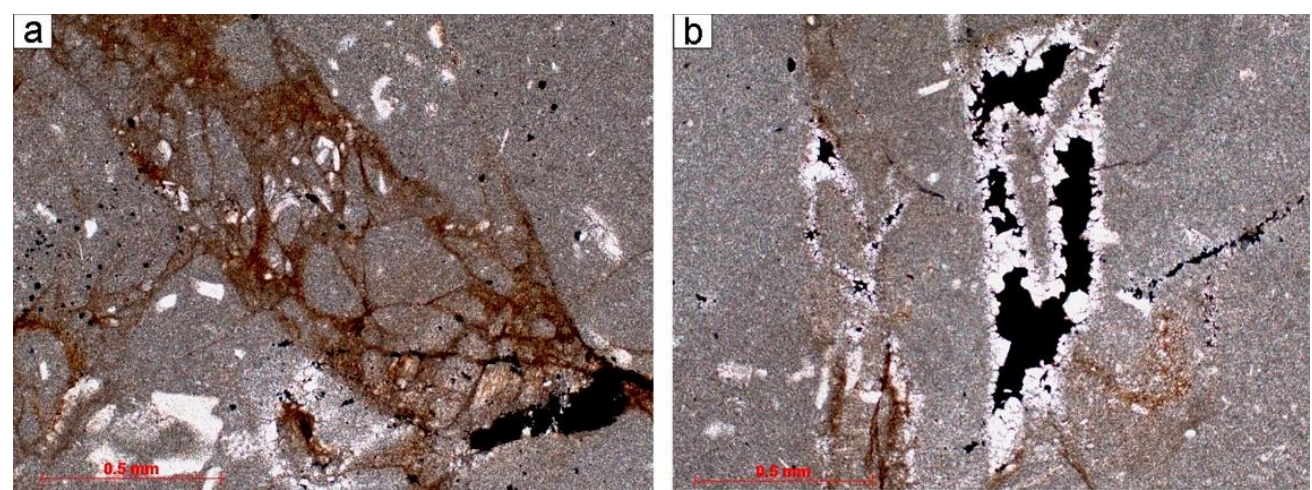

Figure 18. Clayey limestone. Photo of thin section in plane-polarized light. Bituminous filling: (a) in the cataclastic zones, $(\mathbf{b})$ - in the vug with calcite mineralization. Sample depth $381.14 \mathrm{~m}\left(5^{\text {th }}\right.$ unit).
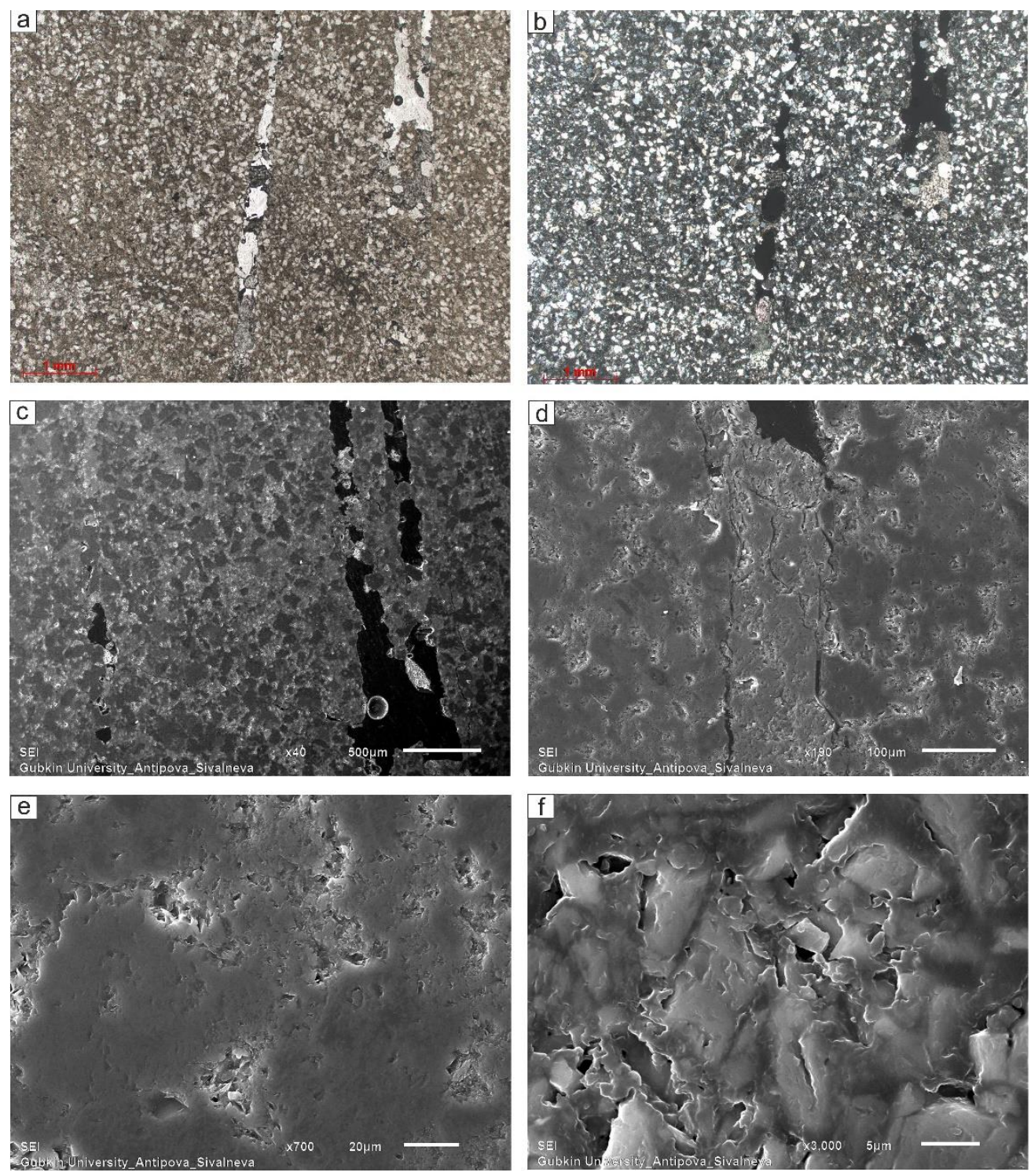

Figure 19. Micro-porosity in the cataclase zone developed along the fracture: photo of thin section (a) -in plane-polarized light, (b) - with crossed polars, (c, d, e, f) - sample photos under SEM with different magnification. Sample depth $531.67 \mathrm{~m}$ ( $3^{\text {rd }}$ unit). 
Each geometry segment includes a set of morphological attributes such as area, perimeter, form factor, aspect ratio, orientation of main axis of inertia, among others. Statistical processing of the obtained data results in a numerical model of structural-textural features of the rocks, which includes the percentage of each component in the test image (Fig. 20, Table 2) and an estimation of their geometry.

The result using ten rock samples are as follows:

- «Rock matrix»-52.85-89.14\%

- «Calcite filling zone» $-0.68-24.87 \%$

- «Micro-porosity zone»-7.16-28.98\%.

- «Open vugs»-0-3.85\%.

Open void space has a square range of 0.83 to $11.07 \mathrm{~mm}^{2}($ Medium $=2.73)$. The range of length along the longest axis is 1.94-6.27 $\mathrm{mm}$ (Medium = 5.24). The ratio of maximum and minimum sizes of 0.19 to 0.71 , respectively, characterized the object shape as elongated.

Although the percentage of open vugs is not high, their geometric parameters correspond to high connectivity that results in good reservoir properties. Additionally, microporosity space may be considered as an effective volume for gas storage (Drake et al. 2019).
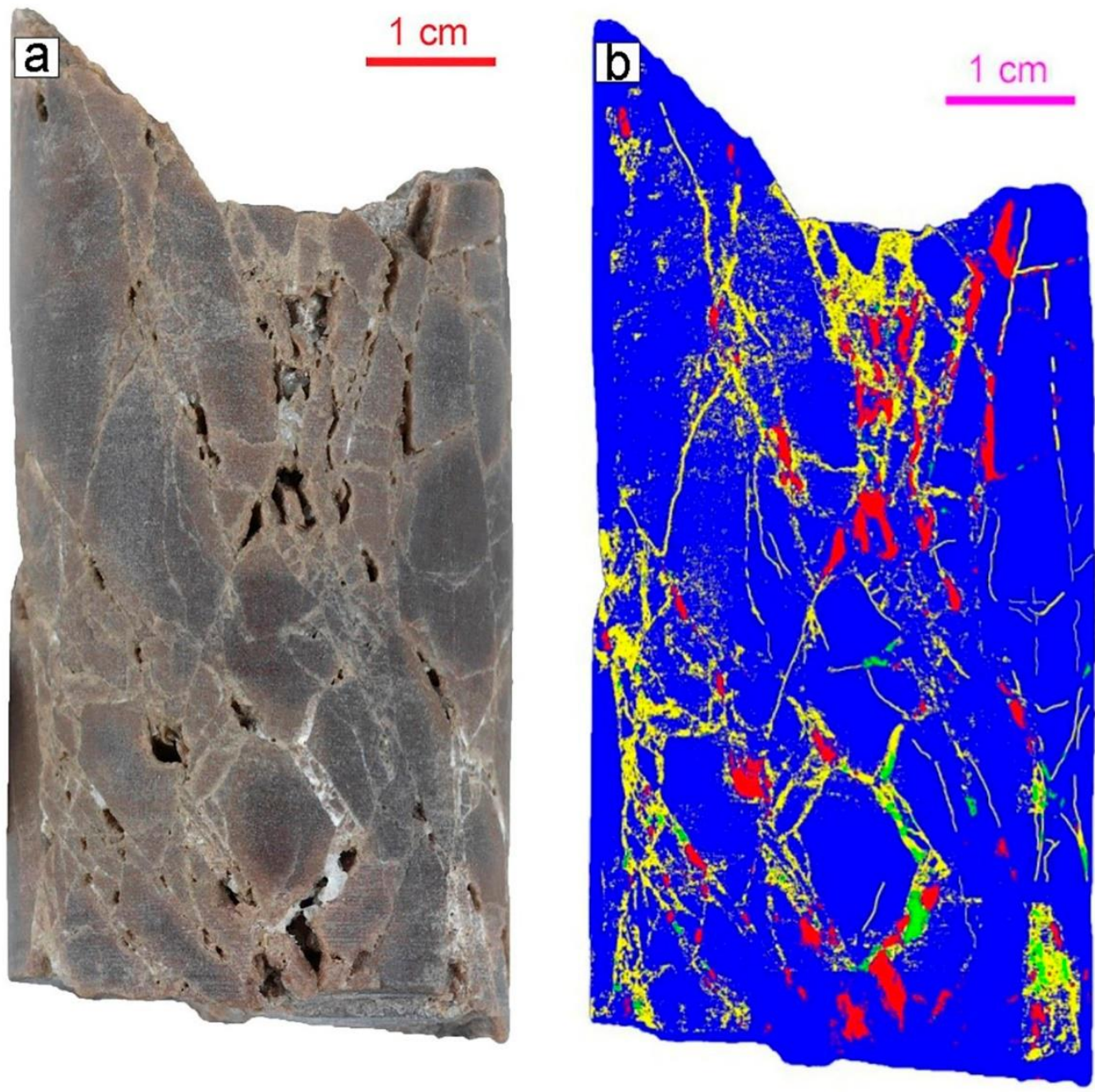

Figure 20. "Image analysis" for the sericite-albite-quartz silty metasandstone: (a) - sample photo, (b) - macro-component areas. Sample depth $531.67 \mathrm{~m}$ (3 $3^{\text {rd }}$ unit). 
Table 2. Results of macro-component modeling of sericite-albite-quartz silty metasandstones.

\begin{tabular}{ccc}
\hline Symbol & Modeling macro-components & Content (\%) \\
\hline «Rock matrix» & 81.45 \\
«Calcite filling zone» & 0.68 \\
«Micro-porosity zone» & 14.03 \\
\hline "Open vugs» & 3.85 \\
\hline
\end{tabular}

\section{Discussion}

Petrologic investigations allow the suggesting of the geological evolution and tectonic settings in the southwestern part of the Siljan Ring.

In the basement section, we can see two units with a prevalence of meta-sedimentary rocks - unit 1 and unit 3, that mainly consist of metasiltstones and metasandstones, respectively. This evidence more likely reveals two cycles of Paleoproterozoic clastic sedimentation separated by a phase of volcanic activity, i.e., unit 2 that consists of metatuffs. In comparison, unit 3 is more coarse-grained than unit 1 (sand and silt), thus may be result of increasing sedimentary basin loading due to the start of regional tectonic movements, a new volcanic activity stage. That stage corresponds to unit 4 composed of metatuffs. A gabbro-dolerite intrusion in the upper part of this unit reveals a phase of tectonic reactivation, which was completely different from previous stages in regard to magma content and pressure-temperature $(\mathrm{P}-\mathrm{T})$ conditions.

Structures of the basement rocks are predominantly primary, e.g., horizontal, lenticular bedding, massive, and the lowest grades of metamorphism may be revealed only by mineralogical changes, such as fine-grained sericite and albite neoformation.

There is no evidence of a normal sedimentary contact between basement and sedimentary cover, such as the transition to Lower Ordovician glauconitic limestone in the Mora 1 drill core, or Obolus beds in Solberga 1 drill core.

The lower part of the sedimentary section is most likely composed of Upper Ordovician sediments intercalated with layers of Fjäcka Shale, and obviously allochthone if compared with the stratigraphic diagram of this region $[3,7,17,18]$. Thus, it may be stated that a significant part of the (Lower and Middle) Ordovician succession is missing as a result of tectonic displacements.

The presence of Fjäcka Shale in the upper part of section (9th unit), between the suggested Lower Silurian sediments, may also be interpreted as a slice of sedimentary deposits that were moved during a phase of tectonic reactivation.

The discovery of crushed zones with rock alteration, such as cataclase and recrystallization (10th unit, Lower Silurian), are probably confined to fault planes. These fault planes might not be accompanied by thrusting or other significant changes in the stratigraphy position of layers.

Although obvious tectonic deformation occurred, structures, textures and composition of the sedimentary rocks suggest a marine shelf environment, probably a sublittoral zone with unfavorable conditions for high-relief organic buildup development. High clay content (up to 10\%) in limestones, diversity of neritic fauna (trilobite, hyolithid, bryozoans) is evidence for such types of environment. Black shale and shale layers mark the establishment of maximum transgression. There is evidence of regression only in the upper part of the section, i.e., the Lower Silurian sediments. The sedimentary transition from greenish-gray and reddish clayey limestones to light-gray sandstones suggests the 
presence of an unconformity and the start of a new cycle of clastic deposition during the Silurian.

Establishing fracture generations enables the reconstruction of Neo- and Post-Proterozoic tectonic events. The four generations recognized in the C-C-1 drill core correspond to four stages of tectonic reactivation.

The first two are established only in basement rocks and were accompanied by hydrothermal circulations. The first stage resulted in quartz mineralization while the second resulted in calcite mineralization. Thus, changes in the chemical composition of fluids are obvious. However, the inheritable sequence of mineralization, possibly reveals its correspondence to the same time of fracturing phases.

The third stage, accompanied by the formation of cataclastics, may be the result of an impact event that created the Siljan Ring impact structure, though that is only one possible explanation. The fourth fracture generation crosses previous ones; therefore, it is suggested to be the result of the latest tectonic movements.

Some of the open vugs has been developed along the second fracture generation. The open space has been formed as a result of incomplete calcite filling or subsequent calcite dissolution. This network of open fractures with vugs may be considered as an effective storage space for hydrocarbons.

Possible effective gas storage may be found in the micro-porosity space that is confined to cataclastic zones in the basement rocks. The evidence of bituminous filling of such zones in sedimentary rocks is indirect proof of the presence of micro-porosity.

Thus, two out of four recognizable tectonic events caused inheritable reservoir rock formation: the second - which resulted in open fractures, and the third - which caused a cataclase. As a result, the intervals of fractured basement rocks with open vugs are possible reservoir intervals, and the effective pore space may be calculated as a sum of open vugs and micro-porosity zones.

Considering the evidence of bituminous filling of vugs and micro-porosity zones in limestones, it is possible to suggest reservoir presence in sedimentary layers in cases of opened fracture network development, or also them possessing primary pore space.

\section{Conclusions}

This section is not mandatory but can be added to the manuscript if the discussion is unusually long or complex.

The results of the C-C- 1 drill core investigation allow the following conclusions to be drawn:

1. The structure of the basement section reveals some features of the geological evolution of the Proterozoic basin in the Siljan Ring area. Using these data, it is possible to suggest the time of tectonic movements and volcanic activation. Two layers of tuffs and gabbro-dolerite intrusion represent the time of tectonic activation stages. Taking into consideration the petrologic characteristics of the units between them, two clastic sedimentary cycles are identified as being from Proterozoic time: the first with less sedimentary loading (metasiltstones) and the second with loading increase (metasandstones).

Though the basement rock structures show weak dislocations, mineralogical changes, such as fine-grained sericite and albite neoformation, reveal very low-grade metamorphism.

2. Based on the results of the petrologic investigation it is concluded that the sedimentary section is not complete as a result of tectonic displacements, and a significant part of the (Lower and Middle) Ordovician succession is missing. The presence of Fjäcka Shale layers between Upper Ordovician and Lower Silurian sediments are suggested to be a result of thrust formation and there is a possibility of determining fault planes.

Structures, textures and composition of the sedimentary rocks suggest deposition in the sublittoral zone within a marine basin with unfavorable conditions for high-relief organic buildup development. Hence, black shale and shale layers were likely formed at the time of maximum transgression. 
3. There are four fracture generations, which correspond to Post-Proterozoic tectonic reactivation stages. These are recognizable by mineralization sequences and fracture interrelations. The first and second generations are present only in the basement rocks and are characterized by quartz and calcite filling. The third generation is accompanied by cataclastic zones. The fourth-generation fractures cut through all of the previous and probably reveals new tectonic reactivation.

4. In the C-C-1 core, reservoir rocks are fractured basement rocks that have a valuable amount of pore space. Porosity zones developed along fractures; two types can be distinguished. The first, open vugs, formed in albite-quartz metasandstones and sericite albitequartz silty metasandstones along the second-generation fractures, have been partially filled by calcite. The second type, micro-porosity zones, occur in cataclastic rock along third generation fractures. This has been confirmed by the investigation with scanning electron microscope (SEM).

5. Results of "image analysis" provide a basis for numerical modeling of structuraltextural rock features. It includes the percentage of such components as "Rock matrix», «Calcite filling zone», «Micro-porosity zone» and «Open vugs».

The «Micro-porosity zone» and «Open vugs» are considered as valuable space for hydrocarbon storage. Their percentage may be included as an additional coefficient in petrophysical data that is used in resources evaluation.

Author Contributions: “Conceptualization, A.P. (Alexandr Postnikov), O.S. (Olga Sivalneva), V.K. (Vladimir Kutcherov) and A.B. (Alexandr Buzilov); methodology, A.P. (Alexandr Postnikov), O.S. (Olga Sivalneva) and A.B. (Alexandr Buzilov); investigation, O.S. (Olga Sivalneva), A.B. (Alexandr Buzilov), M.T. (Marianna Tuchkova), I.S. (Ilnur Sabirov), E.I. (Elisaveta Idrisova); resources, V.K. (Vladimir Kutcherov) and V.M. (Viktor Martynov).; writing - original draft preparation, O.S. (Olga Sivalneva), M.T. (Marianna Tuchkova), I.S. (Ilnur Sabirov), E.I. (Elisaveta Idrisova); writing - review and editing O.S. (Olga Sivalneva), M.T. (Marianna Tuchkova); visualization, O.S. (Olga Sivalneva) and A.B. (Alexandr Buzilov); supervision, A.P. (Alexandr Postnikov), O.S. (Olga Sivalneva), V.K. (Vladimir Kutcherov). All authors have read and agreed to the published version of the manuscript.

Funding: This research received no external funding.

Acknowledgments: The article benefited from support of the Swedish company Igrene AB. Authors thank colleagues from Department of Lithology (Gubkin University of Oil and Gas) for their helpful comments and suggestions.

Conflicts of Interest: The authors declare no conflict of interest.

\section{References}

1. Ahmed, M., Lehnert, O., Fuentes, D., Meinhold, G. Origin of oil and bitumen in the Late Devonian Siljan impact structure, central Sweden. Organic Geochemistry. 2014, 68, 13-26.

2. Arslan, A., Meinhold, G., Lehnert, O. Ordovician sediments sandwiched between Proterozoic basement slivers: tectonic structures in the Stumsnäs 1drill core from the Siljan Ring, central Sweden. GFF. 2013, 135, 213-227.

3. Bergström, S.M. The Ordovician conodont biostratigraphy in the Siljan region, south-central Sweden: a brief review of an international reference standard. In Ebbestad, J.O.R., Wickström, L.M. \& Högström, A.E.S. (eds.): WOGOGOB 2007. 9th meeting of the working group on Ordovician Geology of Baltoscandia. Field Guide and Abstracts. Sveriges Geologiska Undersökning Rapporter och Meddelanden. 2007, 128, 63-78.

4. Bergström, S.M., Calner, M., Lehnert, O. \& Noor, A. A new upper Middle Ordovician-Lower Silurian drillcore standard succession from Borenshult in Östergötland, southern Sweden: 1. Stratigraphical review with regional comparisons. GFF. 2011, 133, 149-171.

5. Calner, M., Lehnert, O. \& Joachimski, M. Carbonate mud mounds, conglomerates, and sea-level history in the Katian (Upper Ordovician) of central Sweden. Facies. 2010, 56, $157-172$.

6. Drake, H., N. M. W. Roberts, C. Heim, M. J. Whitehouse, S. Siljestrom, E. Kooijman, C. Broman, M. Ivarsson \& M. E. Astrom Timing and origin of natural gas accumulation in the Siljan impact structure, Sweden. Nature Communications. 2019, 10:4736, https://doi.org/10.1038/s41467-019-12728-y

7. Ebbestad, J.O.R. \& Högström, A.E.S. Ordovician of the Siljan district, Sweden. In Ebbestad, J.O.R., Wickström, L.M. \& Högström, A.E.S. (eds.): WOGOGOB 2007. 9th meeting of the Working Group on Ordovician Geology of Baltoscandia. Field guide and Abstracts. Sveriges Geologiska Undersökning Rapporter och meddelanden. 2007, 128, 7-26.

8. Frost B.R., Frost C.D. Essentials of Igneous and Metamorphic Petrology. Cambridge University Press, New York, USA, 2011; 314p. 
9. Harbe, M., Juhlin, C., Lehnert, O., Meinhold, G., Andersson, M., Juanateya, M.G., Malehmir, A. Analysis of borehole geophysical data from the Mora area of the Siljan Ring impact structure, central Sweden. Journal of Applied Geophysics. 2015, 115, $183-196$.

10. Harbe, M., Juhlin, C., Sopher, D., Lehnert, O., Arslan, A., Meinhold, G. High-resolution seismic images of Paleozoic rocks in the Mora area, Siljan Ring structure, central Sweden. GFF. 2017, 139:4, 260-275.

11. Harbe, M., Juhlin, C., Malehmir, A., Sopher, D. Integrated interpretation of geophysical data of the Paleozoic structure in the northwestern part of the Siljan Ring impact crater, central Sweden. Journal of Applied Geophysics. 2017, 148, $201-215$.

12. Högström, A.E.S., Sturkell, E., Ebbestad, J.O.R., Lindström, M. \& Ormö, J. Concentric impact structures in the Palaeozoic of Sweden - the Lockne and Siljan craters. GFF. 2010, 132, 65-70.

13. Holm, S., Alwmark, C., Alvarez, W., Schmitz, B. Shock barometry of the Siljan impact structure, Sweden. Meteorit. Planet. Sci. 2011, 46, 1888-1909.

14. Jourdan, F., Reimold, W.U. \& Deutsch, A. Dating terrestrial impact structures. Elements. 2012, 8, 49 -53.

15. Juhlin, C., Pedersen, L.B. Reflection seismic investigations of the Siljan impact structure, Sweden. Journal of Geophysical Research. 1987, 92, 14113-14122.

16. Juhlin, C., Sturkell, E., Ebbestad, J.O.R., Lehnert, O., Högström, A.E.S., Meinhold, G. A new interpretation of the sedimentary cover in the western Siljan Ring area, central Sweden, based on seismic data. Tectonophysics. 2012, 860, 88-99

17. Lehnert, O., Meinhold, G., Bergström, S.M., Calner, M., Ebbestad, J.O.R., Egenhoff, S., Frisk, Å.M., Hannah, J.L., Högström, A.E.S., Huff, W.D., Juhlin, C., Maletz, J., Stein, H.J., Sturkell, E., Vandenbroucke, T.R.A. New Ordovician-Silurian drill cores from the Siljan impact structure in central Sweden: an integral part of the Swedish Deep Drilling Program. GFF. 2012, 134, 8798.

18. Lehnert, O., Meinhold, G., Arslan, A., Ebbestad, J.O.R., Calner, M. Ordovician stratigraphy of the Stumsnäs 1 core from the southern part of the Siljan Ring, central Sweden. GFF. 2013, 135, 204-212.

19. Maleev, E.F. Volcanic Rocks. Handbook. (In Russian). Nedra, Moscow, Russia, 1980; 240 pp.

20. Polovinkina, Y.I. Texture and Structure Igneous and Metamorphic rocks. Part 2. Volume 2. Metamorhic Rocks. (In Russian). Nedra, Moscow, Russia, 1966; 240 pp.

21. Reimold, W.U., Kelley, S.P., Sherlock, S., Henkel, H. \& Koeberl, C., 2005: Laser argon dating of melt breccias from the Siljan impact structure, Sweden: implications for a possible relationship to late Devonian extinction events. Meteoritics and Planetary Science 40, 1-17

22. Robertson, S. BGS Rock Classification Scheme. Volume 2. Classification of metamorphic rocks. British Geological Survey Research Report, RR 99-02. NERC, British Geological Survey, Keyworth, Nottingham, UK, 1999. 